\title{
Probiotics and immunity
}

\author{
Andrea T. Borchers ${ }^{1}$, Carlo Selmi $^{2,3}$, Frederick J. Meyers $^{4}$, Carl L. Keen ${ }^{1}$, and M. Eric Gershwin ${ }^{2}$ \\ ${ }^{1}$ Department of Nutrition, Allergy and Clinical Immunology, University of California at Davis, Davis, CA, USA \\ ${ }^{2}$ Division of Rheumatology, Allergy and Clinical Immunology, University of California at Davis, Genome and Biomedical Sciences Facility, \\ 451 Health Sciences Drive, Suite 6510, Davis, CA 95616, USA \\ ${ }^{3}$ Department of Internal Medicine, IRCCS Istituto Clinico Humanitas, University of Milan, Milan, Italy \\ ${ }^{4}$ Department of Internal Medicine, University of California at Davis Medical Center, Sacramento, CA, USA
}

Probiotics are defined as live microorganisms that, when administered in adequate amounts, confer a health benefit on the host, including the gastrointestinal tract. While this beneficial effect was originally thought to stem from improvements in the intestinal microbial balance, there is now substantial evidence that probiotics can also provide benefits by modulating immune functions. In animal models, probiotic supplementation is able to provide protection from spontaneous and chemically induced colitis by downregulating inflammatory cytokines or inducing regulatory mechanisms in a strain-specific manner. In animal models of allergen sensitization and murine models of asthma and allergic rhinitis, orally administered probiotics can straindependently decrease allergen-specific IgE production, in part by modulating systemic cytokine production. Certain probiotics have been shown to decrease airway hyperresponsiveness and inflammation by inducing regulatory mechanisms. Promising results have been obtained with probiotics in the treatment of human inflammatory diseases of the intestine and in the prevention and treatment of atopic eczema in neonates and infants. However, the findings are too variable to allow firm conclusions as to the effectiveness of specific probiotics in these conditions.

Key words: microflora, nutritional immunology, dietary supplement, innate immunity, vaccine

\section{Introduction}

The gastrointestinal tract constitutes an important interface between host and environment and, as such, has the

Received: September 3, 2008 / Accepted: September 3, 2008 Reprint requests to: M. E. Gershwin dual role of excluding pathogens while facilitating the absorption of nutrients. It is colonized by an estimated $10^{14}$ microbes, with the density of colonization increasing from the stomach to the distal colon. Only a minority (300-500) of the species present in the intestinal microflora can currently be cultured in vitro, whereas a vast majority of intestinal microorganisms cannot. Commensal bacteria participate in both tasks of the gastrointestinal tract: some help in the absorption of otherwise indigestible nutrients, especially complex carbohydrates, and some contribute to colonization resistance, that is, the ability to inhibit colonization or overgrowth of potentially pathogenic microorganisms, by producing antimicrobial substances, competing for adhesion sites and nutrients, and stimulating the immune system.

Recent research efforts have demonstrated that inflammation and immunity changes in general are critical to the development of nearly every complex condition, as well represented by the autoimmunity scenario, which now involves new, previously unsuspected clinical entities $^{1}$ and mechanisms. ${ }^{2}$ Similarly, recent evidence has provided new insights into the immune-mediated mechanisms in metabolic diseases., Taken together, the cumulative data argue for the need to determine new tools to modulate immunity either by enhancing (as in the case of immunodeficiencies) or by suppressing (such as in the case of allergy) the immune response, and dietary components are ideal candidates in this regard.

Probiotics are frequently, though not necessarily, commensal bacteria. The most widely accepted definition of probiotics states that they are live microorganisms that, when administered in adequate amounts, confer a health benefit on the host. ${ }^{5}$ In order to qualify as probiotic, microorganisms should fulfill most, if not all, of the criteria listed in Table 1 . The established probiotics that meet these criteria are generally lactic acid bacteria (LAB), most commonly Lactobacillus and Bifidobacterium species, but Lactococcus, Streptococcus, 
Table 1. Criteria for the use of probiotics in humans

Identified at the genus, species, and strain level

- The gold standard for species identification is DNA-DNA hybridization; 16S rRNA sequence determination is a suitable substitute, particularly if phenotypic tests are used for confirmation

- Strain typing should be performed by pulsed-field gel electrophoresis

- Strain should be deposited in an international culture collection

Safe for food and clinical use

- Nonpathogenic

- Not degrading the intestinal mucosa

- Not carrying transferable antibiotic resistance genes

- Not conjugating bile acids

- Susceptible to antibiotics

Able to survive intestinal transit

- Acid and bile tolerant

Able to adhere to mucosal surfaces

Able to colonize the human intestine or vagina (at least temporarily)

Producing antimicrobial substances

Able to antagonize pathogenic bacteria

Possessing clinically documented and validated health effects

- At least one phase 2 study, preferably independent confirmation of results by another center

Stable during processing and storage

and Enterococcus species, as well as some nonpathogenic strains of Escherichia coli, and certain yeast strains also qualify. Numerous other LAB have shown probiotic potential in animal studies. In recent years, evidence has accumulated that probiotic strains can exhibit the same activities as commensal bacteria, including immunomodulation.

Gut-associated lymphoid tissue (GALT) is the largest lymphoid tissue of the human body. Its earliest and largest exposure to microbial antigens occurs during the initial intestinal colonization, which starts at birth. The type of colonizing organisms depends on the mode of birth and the mode of feeding, hygiene levels, and medication use. A fairly stable configuration of permanently colonizing bacteria is reached in children by approximately 4 years of age. The stimuli provided by colonization with commensal bacteria are essential for the development of a fully functional and balanced immune system, including not only homing of $\mathrm{B}$ and $\mathrm{T}$ cells to the lamina propria and expansion and maturation of IgA plasmocytes and IgA production but also the induction of tolerance toward innocuous food and microbial antigens.

GALT can be divided into areas where lymphocytes are scattered throughout the epithelium and the lamina propria and organized lymphoid tissues, including Peyer's patches and mesenteric lymph nodes (MLNs). ${ }^{6}$ Intestinal antigens are delivered to Peyer's patch dendritic cells (DCs) via specialized enterocytes called M cells. In addition, lamina propria DCs have been shown to directly sample antigens, including enteropathogenic and commensal bacteria, in the intestinal lumen via transepithelial dendrites without jeopardizing the integrity of the epithelial barrier. ${ }^{7,8}$ This process can be induced by ligation of any of a variety of Toll-like receptors (TLRs) expressed on epithelial cells. ${ }^{9}$ Whereas priming of T cells in Peyer's patches or MLNs leads to effective local (mucosal) immune responses or tolerance depending on the encountered antigen, systemic immune responses or tolerance to ingested antigens are likely to be generated in the MLNs. ${ }^{6}$ The translocation efficiency of commensal (and presumably probiotic) bacteria depends on the bacterial strain and the luminal concentration, ${ }^{10,11}$ but the percentage of orally administered commensal bacteria that can be recovered from DCs in MLNs is very small. ${ }^{12}$ Efficient killing by macrophages and sequestering in MLN DCs largely prevent commensal bacteria from gaining access to the systemic immune compartment. ${ }^{10,12}$ This indicates that intestinal DC populations are central to the immune-modulating effects of commensal and, by extension, probiotic bacteria.

DCs are critical players in both innate and adaptive immunity since they are the most potent antigenpresenting cells and have the ability to activate naïve $\mathrm{T}$ cells. ${ }^{13}$ In addition, they have a critical role in directing helper T-cell responses toward Th1 or Th2, or regulatory patterns. ${ }^{13}$ Th1 immune responses critically depend on the ability of DCs to produce interleukin (IL)-12 and are characterized by the production of interferon (IFN)$\gamma$ and IL-2, which induce cell-mediated immunity. Th2 immune responses involve IL-4, IL-5, IL-6, and IL-13 and induce humoral immunity. There is now substantial evidence that DCs can direct $\mathrm{T}$ cells to assume regula- 
tory functions and thereby induce oral tolerance. ${ }^{6,14}$ One of the most extensively studied mechanisms for the induction of regulatory $\mathrm{T}$ cells by DCs is the release of IL-10 or transforming growth factor (TGF)- $\beta$, resulting in $\mathrm{Tr} 1$ and Th 3 cells regulatory $\mathrm{T}$ cells that act through the secretion of IL-10 and TGF- $\beta$, respectively. Other mechanisms involve the production of immunosuppressive IFN- $\alpha$ or the induction of indoleamine 2,3dioxygenase (IDO), which is an immunoregulatory enzyme with key functions in the interactions between DCs and regulatory $\mathrm{T}$ cells that ultimately result in immunosuppression. DC immaturity or partial maturation at the time of antigen presentation has also been implicated in tolerance induction, ${ }^{15}$ particularly as a result of their interaction with apoptotic cells. ${ }^{16}$ Since tolerance to innocuous food and commensal antigens is a prerequisite for gastrointestinal immune homeostasis, it is not surprising that intestinal DCs differ phenotypically, and functionally, from peripheral DCs in that they preferentially prime antigen-specific CD4+ T cells to produce Th2 cytokines or to differentiate into regulatory $\mathrm{T}$ cells and induce tolerance. ${ }^{6,14}$ Yet, it remains unclear whether this tolerogenic phenotype of intestinal DCs is due to their derivation from distinct lineages, their tissue microenvironment, or, in the case of commensal and other nonpathogenic bacteria, to differential stimuli provided by key bacterial components. For further data on mucosal immunity and its relationship to disease, we refer to the recent literature. ${ }^{17-25}$

\section{In vitro effects of probiotics on DC phenotype and function}

In their immature state, DCs are characterized by high capacity for antigen uptake. ${ }^{13}$ Once they capture an antigen in the presence of appropriate inflammatory stimuli, they migrate to secondary lymphoid organs and simultaneously undergo a maturation process. This process involves the upregulation of major histocompatibility complex (MHC) molecules for antigen presentation and of costimulatory molecules, such as CD40, CD54, CD83, and B7.1 and B7.2 (CD80 and CD86) for effective T-cell stimulation. Phenotypic maturation is accompanied by stimulus-specific enhancement of the production of various cytokines that shape the subsequent $\mathrm{T}, \mathrm{B}$, and natural killer $(\mathrm{NK})$ cell responses. In recent years, numerous studies have examined how known and potential probiotics influence DC maturation and cytokine secretion. Because intestinal DCs are difficult to isolate in sufficient numbers, these experiments have focused almost exclusively on human DCs derived from peripheral blood monocytes and on murine bone marrow-derived DCs (BMDCs). There are indications that DCs from the peripheral compartment respond differently to commensal bacteria than do MLN DCs. ${ }^{26}$ However, there are also data suggesting that the responses of peripheral (human blood) and colonic lamina propria DCs to cell wall components of probiotic strains are qualitatively, though not quantitatively, similar. ${ }^{27}$ However, blood myeloid DCs respond differently from monocyte-derived DCs (MDDCs) to probiotic bacteria of intestinal origin. ${ }^{28}$ Therefore, it remains unclear to what extent the results obtained with MDDCs accurately reflect the responses of at least a subset of intestinal DCs. Nonetheless, as is discussed in other sections of this review, certain characteristics of human MDDCs and murine BMDCs correspond rather well to the results of in vivo studies.

Incubation of live or UV-killed probiotics and other LAB induces distinct and strain-specific maturation and cytokine patterns in both human MDDCs and murine BMDCs (see Tables 2-4). Overall, there are at least two types of LAB: strong and weak inducers of IL-12 and

Table 2. Influence of live probiotic and commensal bacteria on human MDDC maturation and cytokine production

\begin{tabular}{|c|c|c|c|c|c|c|c|c|c|c|}
\hline Bacterium & Strain & $\begin{array}{l}\text { Bacterial dose } \\
\text { (bacteria/DCs) }\end{array}$ & CD80 & CD83 & CD86 & CD40 & MHC II & IL-10 & IL-12 & Ref \\
\hline Lactobacillus gasseri & ATCC 19992 & 1000 & $\uparrow$ & $\uparrow$ & $\uparrow$ & $\uparrow$ & $\uparrow$ & \pm & $\uparrow$ & 34 \\
\hline L. johnsonii & ATCC 33200 & 1000 & $\uparrow$ & $\uparrow$ & $\uparrow$ & $\uparrow$ & $\uparrow$ & \pm & $\uparrow$ & 34 \\
\hline L. plantarum & NCIMB 8826 & 10 & $\uparrow$ & $\uparrow$ & $\uparrow$ & & $\uparrow$ & $\bar{\uparrow}$ & $\uparrow$ & 201 \\
\hline L. plantarum & NCIMB 882 & 10 & $\uparrow$ & $\uparrow$ & & & $\uparrow$ & $\uparrow$ & $\uparrow$ & 41 \\
\hline L. plantarum & ATCC 8014 & 10 & $\uparrow$ & $\uparrow$ & $\uparrow$ & $\uparrow$ & $\uparrow$ & $\uparrow$ & $\uparrow$ & 145 \\
\hline L. reuteri & ATCC 23272 & 1000 & $\uparrow$ & $\uparrow$ & $\uparrow$ & $\uparrow$ & $\uparrow$ & \pm & $\uparrow$ & 34 \\
\hline L. rhamnosus & GG & 5 & $\begin{array}{c}\uparrow \\
\text { (low) }\end{array}$ & $\uparrow$ & $\uparrow$ & & & & \pm & 141 \\
\hline L. rhamnosus & $\begin{array}{l}\text { Numico Research } \\
\text { isolate }\end{array}$ & 20 & & $\uparrow$ & $\uparrow$ & \pm & \pm & & \pm & 35 \\
\hline L. salivarius & W24 & 10 & \pm & & \pm & \pm & \pm & & & 37 \\
\hline Bifidobacterium bifidum & W23 & 10 & \pm & & $\uparrow$ & \pm & $\bar{\uparrow}$ & & & 37 \\
\hline B. infantis & W52 & 10 & \pm & & $\uparrow$ & \pm & $\uparrow$ & & & 37 \\
\hline
\end{tabular}

MDDC, monocyte-derived dendritic cells; MHC, major histocompatibility complex; IL, interleukin; DCs, dendritic cells 
Table 3. Influence of UV-killed probiotic and commensal bacteria on human MDDC maturation and cytokine production

\begin{tabular}{|c|c|c|c|c|c|c|c|c|c|c|}
\hline Bacterium & Strain & Bacterial dose & CD80 & CD83 & CD86 & CD40 & MHC II & IL-10 & IL-12 & Ref \\
\hline L. acidophilus & X37 & $30-50 \mu \mathrm{g} / 1.2 \times 10^{6} \mathrm{DCs}$ & & $\uparrow$ & $\uparrow$ & $\uparrow$ & $\uparrow$ & $\uparrow$ & $\uparrow$ & 30 \\
\hline L. acidophilus & X37 & $25 \mu \mathrm{g} / 10^{6} \mathrm{DCs}$ & $\uparrow$ & $\uparrow$ & $\uparrow$ & & $\uparrow$ & $\uparrow$ & $\uparrow$ & 31 \\
\hline L. acidophilus & X37 & $10^{5^{\circ}}$ & $\uparrow$ & $\uparrow$ & & $\uparrow$ & $\uparrow$ & $\uparrow$ & $\uparrow$ & 28 \\
\hline L. paracasei & DSM 12246 & $25 \mu \mathrm{g} / 10^{6} \mathrm{DCs}$ & $\uparrow$ & $\uparrow$ & & \pm & \pm & $\uparrow$ & $\uparrow($ Slight $)$ & 28,31 \\
\hline L. reuteri & DSM 12246 & $25 \mu \mathrm{g} / 10^{6} \mathrm{DCs}$ & $\uparrow$ & $\uparrow$ & $\uparrow$ & & $\uparrow$ & $\uparrow$ & $\uparrow$ (Slight) & 31 \\
\hline L. reuteri & DSM 12246 & $30-50 \mu \mathrm{g} / 1.2 \times 10^{6} \mathrm{DCs}$ & & $\uparrow$ & $\uparrow$ & $\uparrow$ & $\uparrow$ & $\uparrow$ & \pm & 30 \\
\hline L. rhamnosus & GG & $30-50 \mu \mathrm{g} / 1.2 \times 10^{6} \mathrm{DCs}$ & & $\uparrow$ & $\uparrow$ & $\uparrow$ & $\uparrow$ & $\uparrow($ Slight $)$ & \pm & 30 \\
\hline B. bifidum & S131 & $30-50 \mu \mathrm{g} / 1.2 \times 10^{6} \mathrm{DCs}$ & & $\uparrow$ & $\uparrow$ & $\uparrow$ & $\uparrow$ & $\uparrow$ & \pm & 30 \\
\hline B. bifidum & $\mathrm{S} 13.1$ & $25 \mu \mathrm{g} / 10^{6} \mathrm{DCs}$ & $\uparrow$ & $\uparrow$ & $\uparrow$ & & $\uparrow$ & $\uparrow$ & $\uparrow($ Slight $)$ & 31 \\
\hline B. lactis & Bb12 & $30-50 \mu \mathrm{g} / 1.2 \times 10^{6} \mathrm{DCs}$ & $\uparrow$ & $\uparrow$ & $\uparrow$ & $\uparrow$ & $\uparrow$ & $\uparrow$ & \pm & 30 \\
\hline B. longum & Q45 & $30-50 \mu \mathrm{g} / 1.2 \times 10^{6} \mathrm{DCs}$ & $\uparrow$ & $\uparrow$ & $\uparrow$ & $\uparrow$ & $\uparrow$ & $\uparrow$ & \pm & 30 \\
\hline B. longum & Q46 & $30-50 \mu \mathrm{g} / 1.2 \times 10^{6} \mathrm{DCs}$ & $\uparrow$ & $\uparrow$ & $\uparrow$ & $\uparrow$ & $\uparrow$ & $\uparrow$ & \pm & 30 \\
\hline B. longum & Q46 & $25 \mu \mathrm{g} / 10^{6} \mathrm{DCs}$ & $\uparrow$ & $\uparrow$ & & \pm & \pm & $\uparrow$ & $\uparrow$ (Slight) & 28,31 \\
\hline
\end{tabular}

Table 4. Effect of LAB on murine BMDCs

\begin{tabular}{|c|c|c|c|c|c|c|c|c|}
\hline Bacteria & Strain & Bacterial dose & CD86 & CD40 & MHC II & IL-10 & IL-12 & Reference \\
\hline L. casei $^{a}$ & CHCC3139 & up to $10 \mu \mathrm{g} / 1.4 \times 10^{6} \mathrm{DCs}$ & $\uparrow$ & & $\uparrow$ & $\uparrow$ & $\uparrow$ & 202 \\
\hline L. fermentum ${ }^{a}$ & Lb20 & up to $10 \mu \mathrm{g} / 1.4 \times 10^{6} \mathrm{DCs}$ & $\uparrow$ & & $\uparrow$ & $\uparrow$ & $\uparrow$ & 202 \\
\hline L. johnsonii ${ }^{a}$ & La1 & up to $10 \mu \mathrm{g} / 1.4 \times 10^{6} \mathrm{DCs}$ & $\uparrow$ & & $\uparrow$ & $\uparrow$ & $\uparrow$ & 202 \\
\hline L. plantarum ${ }^{a}$ & Lb1 & up to $10 \mu \mathrm{g} / 1.4 \times 10^{6} \mathrm{DCs}$ & $\uparrow$ & & $\uparrow$ & $\uparrow$ & $\uparrow$ & 202 \\
\hline L. plantarum ${ }^{a}$ & $299 v$ & up to $10 \mu \mathrm{g} / 1.4 \times 10^{6} \mathrm{DCs}$ & $\uparrow$ & & $\uparrow$ & $\uparrow$ & $\begin{array}{l}\text { Little } \\
\text { effect }\end{array}$ & 202 \\
\hline L. reuteri & DSM12246 & up to $10 \mu \mathrm{g} / 1.4 \times 10^{6} \mathrm{DCs}$ & \pm & & $\uparrow$ & $\uparrow$ & $\uparrow$ & 202 \\
\hline L. acidophilus & NCFM & $10: 1$ & $\uparrow$ & $\uparrow$ & $\uparrow$ & $\uparrow$ & $\uparrow$ & 107 \\
\hline L. lactis & MG1363 & $10: 1$ & $\uparrow$ & $\uparrow$ & $\uparrow$ & $\uparrow$ & $\uparrow$ & 107 \\
\hline L. rhamnosus & Lr32 & $10: 1$ & $\begin{array}{c}\text { Moderate } \\
\text { effect }\end{array}$ & \pm & $\begin{array}{l}\text { Little } \\
\text { effect }\end{array}$ & $\begin{array}{l}\text { Little } \\
\text { effect }\end{array}$ & $\begin{array}{l}\text { Little } \\
\text { effect }\end{array}$ & 107 \\
\hline L. salivarius & Ls33 & $10: 1$ & $\begin{array}{c}\text { Moderate } \\
\text { effect }\end{array}$ & $\begin{array}{c}\text { Moderate } \\
\text { effect }\end{array}$ & $\begin{array}{c}\text { Moderate } \\
\text { effect }\end{array}$ & $\begin{array}{l}\text { Little } \\
\quad \text { effect }\end{array}$ & $\begin{array}{l}\text { Little } \\
\quad \text { effect }\end{array}$ & 107 \\
\hline
\end{tabular}

LAB, lactic acid bacteria; BMDCs, bone marrow-derived dendritic cells

${ }^{a}$ Note that Christensen et al. ${ }^{202}$ used $\gamma$-irradiated bacteria

tumor necrosis factor (TNF)- $\alpha$ production; however, almost all of them induce significant, though quite variable, levels of IL-10. Most Bifidobacterium strains stimulate the production of high levels of IL-10, but only modest levels of IL-12 and TNF- $\alpha$, and this is also the pattern seen with Gram-negative bacteria of the intestinal microflora. ${ }^{28-30}$

The results of coincubation experiments indicate that there are considerable interactions between bacterial strains that can result in the inhibition or enhancement of DC maturation and IL-12 and IL-10 induction, depending on the combination. ${ }^{30,31}$ Similar findings have been reported in LAB-stimulated peripheral blood mononuclear cells (PBMCs). ${ }^{32,33}$ This suggests that the intestinal microflora of the host may have a decisive influence on the response to treatment with a specific probiotic. Note, however, that this inhibitory effect of weak IL-12 inducers on the inducing capacity of strong inducers is DC-subset dependent, with inhibition seen in MDDCs, but not in blood myeloid DCs. ${ }^{28}$ Therefore, it remains to be established whether lamina propria DCs are sensitive to the inhibitory effect of the simultaneous presence of strong and weak IL-12 inducers.

DCs that undergo partial or full maturation after incubation with a particular LAB strain also differ in their capacity to stimulate allogeneic/autologous T-cell proliferation and cytokine production ${ }^{27,34-36}$ and to enhance NK cell cytokine production and cytotoxicity. ${ }^{28,31}$ In addition, when DC maturation is induced by lipopolysaccharide (LPS) with or without added TNF- $\alpha$ and IL- $1 \beta$, the mere presence of certain LAB strains during this maturation process affects the ability of DCs to polarize the cytokine production of $\mathrm{CD} 4+\mathrm{T}$ cells. ${ }^{37}$ Using a similar protocol, it can be shown that Lactobacillus rhamnosus GG (LGG) is able to induce T-cell hyporesponsiveness $^{38}$ and that Lactobacillus reuteri 
ASM20016 or Lactobacillus casei NIZO B255, but not Lactobacillus plantarum NIZO B253, are capable of priming DCs for the induction of regulatory T cells. ${ }^{39}$ Similar findings have been reported for Lactobacillus paracasei NCC2461 in mixed lymphocyte reactions using murine splenic CD4+ T cells and allogeneic splenocytes as accessory cells. ${ }^{40}$

\section{Interactions between bacteria, intestinal epithelial cells, and DCs}

There are complex and dynamic interactions between the intestinal epithelium and bacteria on the luminal side, and between the epithelium and the underlying immune system on the basolateral side. Intestinal epithelial cells are able to distinguish pathogenic from nonpathogenic bacteria on the basis of their invasiveness and the presence of flagella, ${ }^{41}$ although the exact mechanisms that allow them to do so are not fully elucidated and likely involve additional mucosal factors. ${ }^{17}$ Intestinal epithelial cells that have encountered certain bacteria participate in the immune response by producing chemokines and cytokines and upregulating adhesion molecules, thereby attracting and activating immune cells.

This aspect has been largely neglected in investigations of the influence of probiotics on DC function. There are, however, studies showing that probiotics and other nonpathogenic LAB or components thereof strain-specifically affect the production of the chemokine IL-8 and of proinflammatory cytokines by intestinal epithelial cells. ${ }^{42-48}$ This ability is further modulated by the presence of leukocytes on the basolateral part of the culture plates. ${ }^{49}$

In turn, experiments where bacteria are added to the apical side and DCs to the basolateral side of an intestinal epithelial cell monolayer show that the presence of intestinal epithelium affects the ability of probiotic and other bacteria to induce DC maturation, and particularly the ratio of IL-10 to IL-12 that these DCs release. $^{41,42}$ In addition, the small fraction of DCs that directly sample bacteria by extending dendrites across the intestinal epithelial layer are activated to a different extent than those that only come into contact with soluble mediators produced by epithelial cells that have encountered these bacteria. ${ }^{41}$ Interestingly, DCs treated with supernatant fractions of epithelial cell-bacteria cocultures or of epithelial cells alone were found to preferentially drive $\mathrm{Th} 2$ or regulatory T-cell responses, that is, to induce a "mucosal" DC phenotype, even though peripheral MDDCs were used in these experiments. ${ }^{41,42}$ The production of TGF- $\beta$ and thymic stromal lymphopoietin by intestinal epithelial cells has been implicated in the induction of this tolerogenic DC phenotype. $^{42,50}$

\section{Probiotics in clinical practice}

\section{Probiotics in inflammatory diseases of the bowel}

Crohn's disease (CD) and ulcerative colitis (UC) are two distinct clinical forms of inflammatory bowel disease (IBD), characterized by chronic relapsing intestinal inflammation that is thought to result, similar to other autoimmune diseases, from complex interactions between genetic ${ }^{51-54}$ environmental, ${ }^{55-60}$ and immunological factors. ${ }^{19,61-64}$ Loss of tolerance to the patient's own commensal flora has been implicated in the development of both diseases. Decreased levels of Bifidobacterium and Lactobacillus strains have been described in fecal samples, whereas raised counts of Enterococcus and Bacteroides species are found in inflamed mucosa of patients with IBD. High levels of inflammatory cytokines (TNF- $\alpha$ and IL-1 $\beta$ ) and IL-8 are produced by inflamed colonic mucosa of both $\mathrm{UC}$ and $\mathrm{CD}$ patients, ${ }^{65-69}$ while the role of autoantibodies remains to be determined. ${ }^{70}$ In addition, lamina propria $\mathrm{T}$ cells from IBD patients secrete elevated levels of IL-6, and IL-6/STAT-3 signaling is upregulated. ${ }^{7172}$ However, there are differences between the two clinical forms of IBD, with lamina propria $T$ cells from $C D$ patients showing Th1 polarization, whereas those of UC patients express Th 2 cytokines. ${ }^{73}$ In addition, there is enhanced production of IL-10 in colonic tissue of UC patients. Interestingly, the vast majority of studies report that natural FoxP3+ CD4+CD25+ regulatory T cells (Tregs) are markedly expanded in colonic lamina propria and MLNs of both UC and CD patients, particularly during active disease, and are functionally normal in vitro. ${ }^{74-78}$ While data in celiac disease are awaited ${ }^{25,79}$ imbalanced microbiota and increased production of proinflammatory cytokines have also been implicated in irritable bowel syndrome (IBS) and in pouchitis. The latter is an inflammatory condition of the ileal reservoir in patients with ileal pouch anal anastomosis, a surgical procedure used in the management of UC. We note recent literature that reviews the issues of inflammation, redox, and autoimmunity. ${ }^{80-88}$

The effectiveness of probiotics in clinical trials with $\mathrm{UC}$ and $\mathrm{CD}$ patients

Because of the potential of certain probiotic strains to influence the intestinal microbial balance, improve mucosal barrier function, and modulate immune responses, there have been numerous randomized controlled clinical trials of probiotic supplementation in IBD patients. Their results indicate that certain probiotics, including E. coli Nissle 1917, LGG, and the probiotic mixture VSL\#3 are as effective as standard therapy (most frequently mesalazine) in inducing or maintaining remission in $\mathrm{UC}$ or maintaining remission 
in $\mathrm{CD}^{73,89-91}$ However, when added to standard therapy, these and other probiotics do not provide additional benefits compared with standard therapy alone, and most of the probiotics tested to date are not more effective than placebo in inducing or maintaining remission in CD or UC. Only the results of some small trials suggest that various combinations of Bifidobacterium strains are superior to placebo in preventing relapse in $\mathrm{UC}$.

Supplementation of UC patients with a combination of Bifidobacterium breve strain Yakult, Bifidobacterium bifidum strain Yakult, and an unspecified strain of Lactobacillus acidophilus was associated with significantly lower clinical activity index, endoscopic activity index, and histological scores compared with mesalazine alone. ${ }^{90}$ In a small study of patients with UC, symbiotic treatment with Bifidobacterium longum plus fructooligosaccharides and inulin, in addition to their existing medical therapy, tended to lower the sigmoidoscopy score $(P=0.06$ compared with placebo $) .{ }^{92}$ Supplementation with a variety of probiotic strains was also reported to be associated with beneficial effects on IBS. $^{73}$ In addition, VSL\#3 was reported to prevent the onset of pouchitis.

The mechanisms by which probiotics might ameliorate IBD, IBS, and pouchitis are rarely addressed in these clinical trials. The symbiotic treatment that tended to lower the sigmoidoscopy score was associated with significantly reduced mRNA expression of TNF- $\alpha$ and IL-1 $\alpha$ in biopsy specimens. ${ }^{92}$ In an open-label study of VSL\#3 in patients that had recovered from acute pouchitis after antibiotic treatment, supplementation with this probiotic mixture also decreased the pouch levels of proinflammatory cytokines (TNF- $\alpha$, IL- $1 \alpha$ and IFN$\gamma$ ), while it increased the production of IL- $10 .{ }^{93}$ Similarly, in patients with IBS, supplementation with Bifidobacterium infantis 35624 or L. rhamnosus GR-1 plus L. reuteri RC-14 decreased IL-12 production and normalized the IL-10:IL-12 ratio. ${ }^{94,95}$ In addition, administration of VSL\#3 resulted in the expansion of colonic Foxp3+ Tregs in conjunction with significantly reduced pouchitis disease activity scores, ${ }^{96}$ and supplementation with $L$. rhamnosus GR-1 and L. reuteri RC-14 was associated with an increased frequency of peripheral Tregs in IBS patients. $^{95}$

In healthy volunteers, it was shown that consumption of LGG led to downregulation of the production of proinflammatory cytokines and enhanced the ex vivo synthesis of IL-4 and IL-10 of their CD4+ T cells in response to stimulation with intestinal bacterial preparations. ${ }^{97}$ Since inflammatory reactions to the host's own microflora are implicated in IBD, the ability of LGG to skew microflora-induced cytokine production toward an anti-inflammatory profile could be of great benefit. Note, however, that intestinal CD4+ T cells from CD patients and healthy volunteers show differential IFN- $\gamma$ and IL-10 responses to stimulation with autologous intestinal bacteria or with sonicates of probiotics. ${ }^{98}$ Therefore, it needs to be established whether LGG supplementation can have the same anti-inflammatory effects in IBD patients as those seen in these healthy volunteers.

Data from in vitro studies with inflamed ileal tissue from CD patients suggest that $L$. casei $\mathrm{DN}-114001$ can not only downregulate TNF- $\alpha$ and IL- 6 production but also increase the percentage of lymphocytes undergoing apoptosis, which may contribute to its ability to diminish the number of activated $\mathrm{T}$ cells in the lamina propria. ${ }^{67-69}$ Downregulation of IL-6, which can exhibit antiapoptotic activity, may play a role in this process. ${ }^{69}$ Indeed, in a mouse model of chronic colitis, treatment with neutralizing IL-6 receptor antibodies prevented macroscopic signs of inflammation in the colon while markedly increasing the number of lamina propria CD4+ T cells undergoing apoptosis. ${ }^{99}$

\section{Probiotics in animal models of colitis}

There are numerous animal models of colitis. Mice deficient in IL-10 or IL-2 (IL-10 $0^{-/}$and IL-2 ${ }^{-/-}$mice) and HLA-B27 transgenic rats spontaneously develop colitis if they are not kept in germ-free conditions, which highlights the importance of the intestinal microflora in these models. Other models of chronic colitis include the transfer of $\mathrm{CD} 4^{+} \mathrm{CD} 45 \mathrm{RB}^{\text {high }}$ or $\mathrm{CD} 4^{+} \mathrm{CD} 62 \mathrm{~L}^{+} \mathrm{T}$ cells into severe combined immunodeficiency (SCID) mice. In addition, chronic colitis can be induced by the intrarectal administration of trinitrobenzene-sulfonic acid (TNBS). In all of these models, colitis is T-cell mediated and involves mononuclear infiltration of the colonic mucosa along with enhanced production of proinflammatory cytokines. Administration of dextran sodium sulfate (DSS) in the drinking water induces a model of acute colitis that requires neither B nor T cells, but is largely macrophage mediated. Although a mononuclear infiltrate is also seen in the colon of DSS-treated mice, the damage is thought to be due mostly to the toxic effects of DDS rather than the inflammation.

Most available studies focused on the role of various probiotic in the prevention of colitis. None of the strains examined to date was completely effective. However, downregulating the production of proinflammatory cytokines and other inflammatory mediators seems to constitute important mechanisms for the partial amelioration of colitis seen with numerous LAB strains in various models. ${ }^{48,100-102}$ Of note, TNF- $\alpha$ blocking agents are also quite successful in the treatment of patients with CD.

In addition, the ability to dampen Th1 responses (IL12 and IFN- $\gamma$ production) has been implicated in the preventative effect of Lactobacillus salivarius subspe- 
cies (ssp.) salivarius 433118 and $B$. infantis $35624,{ }^{103}$ the therapeutic effect of DNA isolated from VSL\#3, ${ }^{48}$ and the partial protection provided by preventative and therapeutic administration of L. plantarum 299v in IL$10^{-/-}$mice. ${ }^{104}$ Interestingly, in SCID mice reconstituted with activated CD4+ T cells or CD4+CD62L+ T cells, preventative treatment with a combination of $L$. reuteri DSM 12246 and L. rhamnosus 19070-2 or with E. coli Nissle was associated with significantly decreased production of Th2 cytokines by polyclonally stimulated MLNs. ${ }^{105,106}$ However, the release of IFN- $\gamma$ was also lower in both studies, although this reached significance only with $E$. coli Nissle. In both cases, IL-10 levels were not significantly affected.

A recent study investigated whether the transfer of LAB-treated DCs could protect mice from the development of TNBS-induced colitis. ${ }^{107}$ Lactobacillus salivarius Ls33 and L. rhamnosus Lr32 were found to be weak inducers of DC maturation and cytokine production. Administration of BMDCs that had been incubated with one of these two LAB strains partially protected mice from TNBS-induced colitis, and this protection was greater than that achieved with intraperitoneal (i.p.) administration of the same LAB strain. This amelioration of colitis was shown to depend on the presence of $\mathrm{CD} 4+\mathrm{CD} 25+$ regulatory $\mathrm{T}$ cells, but to be independent of IL-10. Instead, it was associated with highly increased expression of IDO and IFN- $\gamma$. Production of this cytokine by DCs is known to induce IDO expression. This suggests that the partial maturation of DCs in the presence of L. salivarius Ls33 and L. rhamnosus Lr32 resulted in the induction of a tolerogenic DC phenotype.

Whereas the preceding studies do not provide evidence for a significant role of IL-10, other data suggest an important function for this anti-inflammatory and regulatory cytokine in the protection from recurrence of colitis in HLA-B27 transgenic mice associated with consumption of LGG. ${ }^{102}$ In addition, the ability of various $\mathrm{LAB}$ strains to induce a high ratio of IL-10/IL12 production in human PBMCs correlated with their capacity to provide significant protection from TNBSinduced colitis. ${ }^{108-110}$ Increasing the production of IL-10 by lamina propria $\mathrm{T}$ cells was also found to be an important mechanism in the ability of VSL\#3 to reduce the severity of recurrent colitis induced by readministration of TNBS. ${ }^{111}$ This induction of IL-10 was essential for the expansion of a population of regulatory $T$ cells that was identified as a critical mediator of the amelioration of colitis and possessed characteristics of "natural" Tregs. Note that a role for IL-10 in the expansion of natural Tregs has, to our knowledge, not been previously described, although there are indications that it might be necessary for their functional activation, in particular their ability to release TGF- $\beta .^{112}$ Given the increased frequency and intact in vitro function of Foxp3+ Tregs in colonic lymphoid tissue of IBD patients, the question arises as to whether the induction of such "natural" Tregs is likely to benefit such patients. There are, however, indications that the expansion of Tregs may have protective effects in patients with IBS or pouchitis. ${ }^{95,96}$

Cell wall components of the probiotic mixture VSL\#3 can stimulate the maturation of murine $\mathrm{BMDCs}^{36}$ and strongly induce IL-10 production from human blood and colonic lamina propria DCs. ${ }^{27}$ In addition, they are capable of decreasing basal IL-12 secretion in human blood DCs and of downregulating the LPS-induced increase in the percentage of IL-12-producing blood DCs, while leaving the percentage of IL-10+ DCs unchanged. ${ }^{27}$ When naïve allogeneic CD4+ T cells were activated in the presence of DCs stimulated with VSL\#3 cell wall components, the proportion of IFN- $\gamma$ producing cells was significantly reduced compared to either LPS-treated or unstimulated DCs, while the proportion of IL-4- or IL-10-producing cells was not significantly altered. ${ }^{27}$ These results indicate that cell wall components of VSL\#3 do not prime DCs for the generation of Th1 T-cell responses, but they do not predict the IL-10-dependent induction of regulatory $\mathrm{T}$ cells as seen in TNBS-induced colitis. ${ }^{111}$ It is possible, however, that cell wall components are not responsible for the observed effects.

VSL\#3 also significantly inhibited the development of DSS-induced colitis and had remarkable therapeutic effects in established colitis. ${ }^{113}$ These effects were shown to be due to probiotic DNA, which when given orally could inhibit disease activity and improve histologic scores to a similar extent as whole live bacteria. In addition, a single subcutaneous (s.c.) administration of probiotic DNA protected against TNBS-induced colitis and spontaneous colitis in IL- $10^{-/-}$mice. Of note, intragastric or s.c. administration of E. coli (DH5a) DNA also provided significant protection from DSS-induced colitis. This confirms that immunostimulatory DNA (ISS-DNA) sequences are a common property of certain bacterial and viral genomes. ISS-DNA sequences and their synthetic oligodeoxynucleotide (ODN) analogs contain unmethylated $\mathrm{CpG}$ dinucleotides within consensus sequences, termed $\mathrm{CpG}$ motifs, and can exert a variety of effects on macrophages, NK cells, B cells, and DCs. Studies with other ISS-ODNs in the DSS-induced model of colitis suggest that protection is mainly mediated by the production of immunoregulatory type 1 IFN $($ IFN- $\alpha / \beta)$ by plasmacytoid DCs. ${ }^{114}$ In this model, type 1 IFN acts mainly, but not exclusively, by suppressing the inflammatory response of activated macrophages. Since IFN- $\alpha$ has also been implicated in the regulation of Tcell responses, it will be of interest to determine whether such regulatory mechanisms are operative in VSL\#3- 
associated amelioration of $\mathrm{T}$ cell-mediated models of colitis. In addition, organ culture experiments of colonic biopsy specimens from patients with active UC suggest that reduced production of proinflammatory cytokines is another potential mechanism by which VSL\#3 DNA can protect against intestinal inflammation. ${ }^{66}$

\section{Probiotics in allergic diseases}

Recent decades have witnessed a marked increase in the incidence of atopic diseases in industrialized countries. According to the "hygiene hypothesis," a relative lack of microbial stimuli in infancy and early childhood due to increased hygiene results in an imbalance between Th1- and Th2-type immune responses that favors the development of IgE-mediated allergies. However, over the same period of time, there has also been an increase in the incidence of diseases that are characterized by a predominantly Th1-polarized T-cell response. This suggests that immunoregulatory mechanisms capable of controlling both Th1 and Th2 responses do not fully mature in the relative absence of microbial stimuli. While much research has focused on early exposure to infectious agents, it is becoming increasingly recognized that commensal bacteria, which provide the first and major source of microbial exposure, play a central role not only in Th1/Th2 polarization but also in inducing the appropriate regulatory mechanisms. It is also under investigation what role (if any) probiotics have on $\mathrm{T}$ regulatory cells. ${ }^{115,116}$ There are indications that the composition of commensal bacteria differs between children who develop atopic diseases and those who do not, and between children from countries with a high or low incidence of atopic disease.${ }^{117}$ However, to date, the differences identified are not consistent between studies. In addition, a recent large multinational prospective study failed to detect an association between the time of colonization with any particular culturable bacterial group and the development of atopic eczema or sensitization to food allergens during the first 18 months of life. ${ }^{118}$

Primary allergy prevention trials with probiotics

The hope of altering intestinal microbial balance and thereby modulating the polarization of helper T-cell responses have prompted numerous studies examining the potential role of probiotic strains in the primary prevention or treatment of atopic diseases. To date, the results of five randomized placebo-controlled clinical trials of probiotics in the primary prevention of allergic disease have been published (see Table 5). All of these trials enrolled infants at high risk of developing allergy, usually defined as $\geq 1$ family member having an allergic disease. In all studies except one ${ }^{119}$ the mothers received the supplement for the last weeks of pregnancy. After that, the study design becomes more variable, with the supplement being given to the lactating mother for varying periods, or to the infant directly until 6 months postnatally. Only one study supplemented until 12 months postnatally. ${ }^{120}$ Assessment of allergic manifestations occurred at various time points during the first and/or second year of life. In 2001, Kalliomäki et al. ${ }^{121}$

Table 5. Risk of eczema/atopic dermatitis in randomized placebo-controlled primary prevention trials

\begin{tabular}{|c|c|c|c|c|c|c|c|}
\hline $\begin{array}{l}\text { Study } \\
\text { location }\end{array}$ & $\begin{array}{l}\text { Number of } \\
\text { subjects } \\
\text { randomized/ } \\
\text { completed }\end{array}$ & Bacterial strains & $\begin{array}{c}\text { Daily } \\
\text { bacterial } \\
\text { dose }(\mathrm{cfu})\end{array}$ & Eczema & $\begin{array}{c}\text { IgE-associated } \\
\text { eczema }\end{array}$ & $\begin{array}{l}\text { Other } \\
\text { significant } \\
\text { results }\end{array}$ & Reference \\
\hline $\begin{array}{l}\text { Turku, } \\
\text { Finland }\end{array}$ & $159 / 132$ & LGG & $1 \times 10^{10}$ & $\begin{array}{l}\text { RR } 0.51 \\
\text { (CI, 0.32-0.84) }\end{array}$ & & & 121 \\
\hline $\begin{array}{l}\text { Freiburg, } \\
\text { Germany }\end{array}$ & $105 / 94$ & LGG & $1 \times 10^{10}$ & $\begin{array}{l}\text { OR, } 0.96 \\
(\mathrm{CI}, 0.38-2.33)\end{array}$ & & & 125 \\
\hline $\begin{array}{l}\text { Perth, } \\
\text { Australia }\end{array}$ & $231 / 178$ & $\begin{array}{l}\text { L. acidophilus } \\
\text { LAVRI-A1 }\end{array}$ & $3 \times 10^{9}$ & $\begin{array}{l}\text { No significant } \\
\text { difference }\end{array}$ & $\begin{array}{l}\text { Significantly } \\
\text { higher rate }\end{array}$ & $\begin{array}{l}\text { Significantly } \\
\text { higher rate of } \\
\text { sensitization; }\end{array}$ & 119 \\
\hline Sweden & $232 / 188$ & L. reuteri ATCC 55730 & $1 \times 10^{8}$ & $\begin{array}{l}\text { No significant } \\
\text { difference }\end{array}$ & $\begin{array}{c}\text { OR, 0.36, } \\
P=0.047\end{array}$ & & 120 \\
\hline $\begin{array}{l}\text { Helsinki, } \\
\text { Finland }\end{array}$ & $1223 / 925$ & $\begin{array}{l}\text { LGG, L. rhamnosus } \\
\text { LC705, B. breve Bb99, } \\
\text { P. shermanii JS plus } \\
\text { galactooligosaccharides }\end{array}$ & $2.44 \times 10^{10}$ & $\begin{array}{l}\mathbf{O R}, \mathbf{0 . 7 4} \\
(\mathrm{CI}, 0.55-0.98)\end{array}$ & $\begin{array}{c}\text { OR, 0.66 } \\
(\mathrm{CI}, 0.46- \\
0.95)\end{array}$ & $\begin{array}{l}\text { Tended to } \\
\quad \text { reduce IgE- } \\
\text { associated } \\
\text { diseases: } \\
\text { OR, } 0.71 \\
(0.5-1.00) \\
P=0.052\end{array}$ & 124 \\
\hline
\end{tabular}

Values in bold type designate significant risk reduction

P. shermanii, Propionibacterium freudenreichii ssp. shermanii; RR, relative risk; OR, odds ratio; CI, confidence interval; LGG, Lactobacillus rhamnosus GG 
reported that LGG supplementation of pregnant women and later their infants resulted in a $50 \%$ reduction in the risk of eczema by the age of 2 years. This protective effect was maintained at the ages of 4 and 7 years. ${ }^{122,123}$ However, others were unable to confirm a preventative effect of LGG supplementation, ${ }^{124,125}$ and the results of primary prevention trials using other probiotics are variable and not as impressive as those obtained by Kalliomäki et al. ${ }^{121}$ (as summarized in Table 5).

In the trials that examined the risk of other manifestations of allergic disease, probiotic supplementation did not show significant effects on allergic rhinitis, food hypersensitivity, or asthma. ${ }^{119-121,124}$ In three of the trials, the rates of sensitization also did not differ significantly between the probiotic and the placebo group. ${ }^{121,124,125}$ Supplementation with L. reuteri ATCC 55730 lowered the incidence of skin prick reactivity in infants with mothers with allergies. ${ }^{120}$ In contrast, ingestion of $L$. acidophilus LAVRI for the first 6 months of life raised the rate of sensitization to a variety of food and inhalant allergens tested. ${ }^{119}$ In addition, this and the recent LGG trial showed a significantly greater frequency of wheezing or wheezing bronchitis in the probiotic compared with the placebo groups. ${ }^{119,125}$ Wheezing in infancy may be a risk factor for developing asthma later. Of note, Kalliomäki et al. ${ }^{123}$ reported that the risk of both allergic rhinitis and asthma showed a tendency to be increased in the probiotic (LGG) compared with the placebo group at the 7-year follow-up. This makes it advisable to exert great caution in the use of probiotics in the prevention of allergic disease. Several other primary prevention trials are underway, ${ }^{126}$ and it will be of great interest whether any of them reveal similarly concerning findings.

In the original primary prevention trial with $\mathrm{LGG}^{121}$ analysis of data from a subset of women who breast-fed their infants for at least 3 months suggested that LGG supplementation of mothers during late pregnancy and lactation reduced the incidence of atopic eczema in their infants by increasing immunosuppressive TGF- $\beta 2$ levels in breast milk. ${ }^{127}$ In another study, however, low, rather than high, TGF- $\beta 2$ levels in colostrum and milk tended to be associated with reduced sensitization and decreased incidence of IgE-associated eczema. ${ }^{128}$

The induction of low-grade inflammation has been proposed as a mechanism of the prevention of eczema by supplementation with LGG, L. rhamnosus LC705, B. breve Bb99, and Propionibacterium freudenreichii ssp. shermanii in combination with a prebiotic. ${ }^{124,129}$ This was based on an analysis of plasma levels of cytokines and inflammatory markers in a randomly selected subgroup of participants in a large primary prevention trial, which indicated that increased plasma C-reactive protein (CRP) concentrations in infants at 6 months of age were associated with decreased risk of eczema and allergic disease at 2 years of age after adjustment for probiotic use. $^{129}$ This was also observed in a separate analysis of the placebo group. Plasma IL-10 concentrations were higher in the probiotic group and, paradoxically, correlated positively with CRP. Induction of low-grade inflammation has also been proposed as a mechanism for therapeutic effects of probiotic supplementation in atopic dermatitis. ${ }^{130}$ Interestingly, in that trial the very same combination of probiotics was used, but without added prebiotic, and was not found to have an inflammatory effect but to also increase serum IL-10 levels. In contrast, treatment with LGG alone was associated with increased serum CRP and IL-6 concentrations in the subgroup of children with IgE-associated atopic eczema/ dermatitis syndrome.

\section{Clinical trials of probiotics in the treatment of allergic diseases}

Studies in adults have largely not revealed any significant effect of probiotic supplementation in allergic rhinitis or asthma, ${ }^{126}$ with the exception of several Japanese trials that suggest improved symptom/medication scores in patients with allergic rhinitis. However, the above studies are difficult to critically evaluate because of a lack of detailed information on the methods and procedures. Several clinical trials addressed the effectiveness of probiotic supplementation compared with placebo in the treatment of eczema or atopic dermatitis in infants or children. Ingestion of LGG for periods ranging from 4 to 12 weeks has been associated with significant decreases or greater changes in Scoring Atopic Dermatitis (SCORAD) scores compared with placebo in some small studies, but not in several more recent and larger trials. Others were unable to detect significant differences in the group overall, but found the LGGassociated improvements to be significant in subgroups of children with IgE-associated disease. ${ }^{131}$ In the same study, a combination of four probiotics (LGG, L. rhamnosus LC705, B. breve Bb99, and Propionibacterium freudenreichii ssp. shermanii) did not have a significant effect. ${ }^{131}$ Interestingly, the same four probiotics given in combination with a prebiotic reduced the incidence of eczema and atopic eczema and tended to reduce $\mathrm{IgE}$ associated diseases overall in a primary prevention trial. $^{124}$ This may suggest that probiotics have different effects in developing compared with in established disease. Alternatively, the addition of prebiotic galactooligosaccharides may have been the decisive difference, although clear evidence of its bifidogenic effect is still lacking. The combination of L. rhamnosus plus Bifidobacterium lactis (the strains were not specified) also significantly improved SCORAD scores only in the subset of food-sensitized children. ${ }^{132}$ In young children (aged 6-18 months) with moderate or severe atopic dermatitis, supplementation with Lactobacillus fermen- 
tum VRI 003 PCC or placebo for 8 weeks was associated with a significant reduction in the SCORAD index in the probiotic group, but not in the placebo group, although the difference between the groups after 16 weeks was not statistically significant. ${ }^{133}$

Cytokine production by PBMCs in response to polyclonal stimuli was not affected in participants of trials where probiotic supplementation did not show a significant effect. ${ }^{134,135}$ In contrast, improvements in SCORAD scores were associated with increased IFN- $\gamma$ production in studies where probiotic supplementation was beneficial at least in certain subgroups of patients. ${ }^{136,137}$ In addition, the induction of low-grade inflammation, as indicated by increased serum CRP and IL-6 levels, has been proposed as a mechanism. ${ }^{130}$ Note, however, that in the above study, serum cytokine concentrations were below the detection limit in the majority of samples, including in almost $80 \%$ of the IL-6 samples. In the other studies, sufficient blood samples were available only from subsets of study participants and no information was provided on how representative these children were of the whole study population..$^{136,137}$ In addition, in one of these investigations significant differences in baseline IFN- $\gamma$ production between the probiotic and placebo groups were not taken into account, raising the question of whether the observed effects were really attributable to probiotic supplementation, particularly given that allergen-specific IFN- $\gamma$ responses were not significantly altered. ${ }^{137}$

Probiotics in animal models of sensitization and allergic manifestations

Because of these methodological shortcomings, the available data from clinical trials provides little insight into the mechanisms accounting for the strain-specific benefits of probiotic supplementation. Animal studies are beginning to unravel some of the immunological changes that accompany ingestion of established and potential probiotics and that may be of benefit in allergic diseases. Most of these studies have focused on the sensitization process, which generally is not affected by probiotic supplementation in primary prevention trials. The most frequently used animal model of sensitization takes advantage of the fact that $\mathrm{Balb} / \mathrm{c}$ mice are genetically predisposed toward the elaboration of Th2polarized T-cell responses. These mice are injected i.p. with antigen, most commonly ovalbumin (OVA), in conjunction with aluminum hydroxide or a similar adjuvant. The effects of oral supplementation with various probiotic strains are then assessed by measuring serum levels of antigen-specific and total $\mathrm{IgE}$ production and the elaboration of Th1 and Th2 cytokines in splenocytes restimulated with OVA ex vivo.

The available data indicate that numerous LAB strains are capable of inhibiting total and OVA-specific
IgE production when administered orally before or concomitant with sensitization (see Table 6). Notably, many strains are effective even when heat-killed (see Table 7). The associated cytokine patterns in OVA-stimulated splenocytes from LAB-fed mice are highly strain dependent and indicate that different mechanisms are involved. As summarized in Tables 6 and 7, reduced serum levels of OVA-specific IgE can be associated with enhanced production of Th1 cytokines, decreased synthesis of Th2 cytokines, or both. However, in several studies IFN- $\gamma$ production has been reported to be unaffected or even reduced, and in some instances both Th1 and Th2 cytokines are downregulated. In contrast, oral administration of L. rhamnosus HN001 before and during OVA sensitization increased both Th1 (IL12 , IL-18, and IFN- $\gamma$ ) and Th2 (IL-4 and IL-5) cytokines in splenocytes restimulated with OVA ex vivo. ${ }^{138}$ Unfortunately, OVA-specific or total IgE levels were not determined in this study.

Two studies examined the effect of oral probiotic administration in murine models of asthma, in which i.p. sensitization with OVA was followed by intranasal OVA challenge. ${ }^{139,140}$ Note that one of these studies used a design resembling that of human primary prevention trials in that the probiotic supplementation was started at birth and continued throughout sensitization and challenge. ${ }^{140}$ In these studies, oral administration of $L$. reuteri ATCC $23272,{ }^{139}$ LGG, or Bifidobacterium animalis ssp. lactis $\mathrm{Bb}-12^{140}$ significantly decreased airway hyperresponsiveness and the influx of eosinophils and macrophages in bronchoalveolar lavage fluid obtained $24 \mathrm{~h}$ after intranasal challenge. This was not associated with a Th1 polarization of the cytokine response in either of the studies. Instead, upregulation of systemic, though not pulmonary, activity of IDO was observed after oral administration of L. reuteri ATCC $23272 .{ }^{139}$ IDO is an important immune control enzyme and mediator of peripheral tolerance, and its stimulation suggests the induction of regulatory mechanisms. Such a mechanism was shown more directly to be involved in the dampening of airway hyperreactivity after oral administration of LGG or B. animalis ssp. lactis Bb12. ${ }^{140}$ Both probiotics significantly increased the number of natural Tregs (Foxp3+ CD4+ T cells) in the lungs of asthmatic mice, with $\mathrm{Bb}-12$ showing greater effectiveness. Note that both Bb-12 and LGG induce only weak or partial maturation and little IL-12 production in human MDDCs. ${ }^{30,141}$ Whereas Bb-12 strongly stimulates MDDC synthesis of IL-10, LGG only moderately enhances it. Similar results have been reported from in vitro stimulation of human PBMCs with these LAB strains. ${ }^{33,142-144}$ These in vitro results are in keeping with the ability of these probiotic strains to induce regulatory mechanisms, rather than Th1 cytokine polarization, in vivo. 


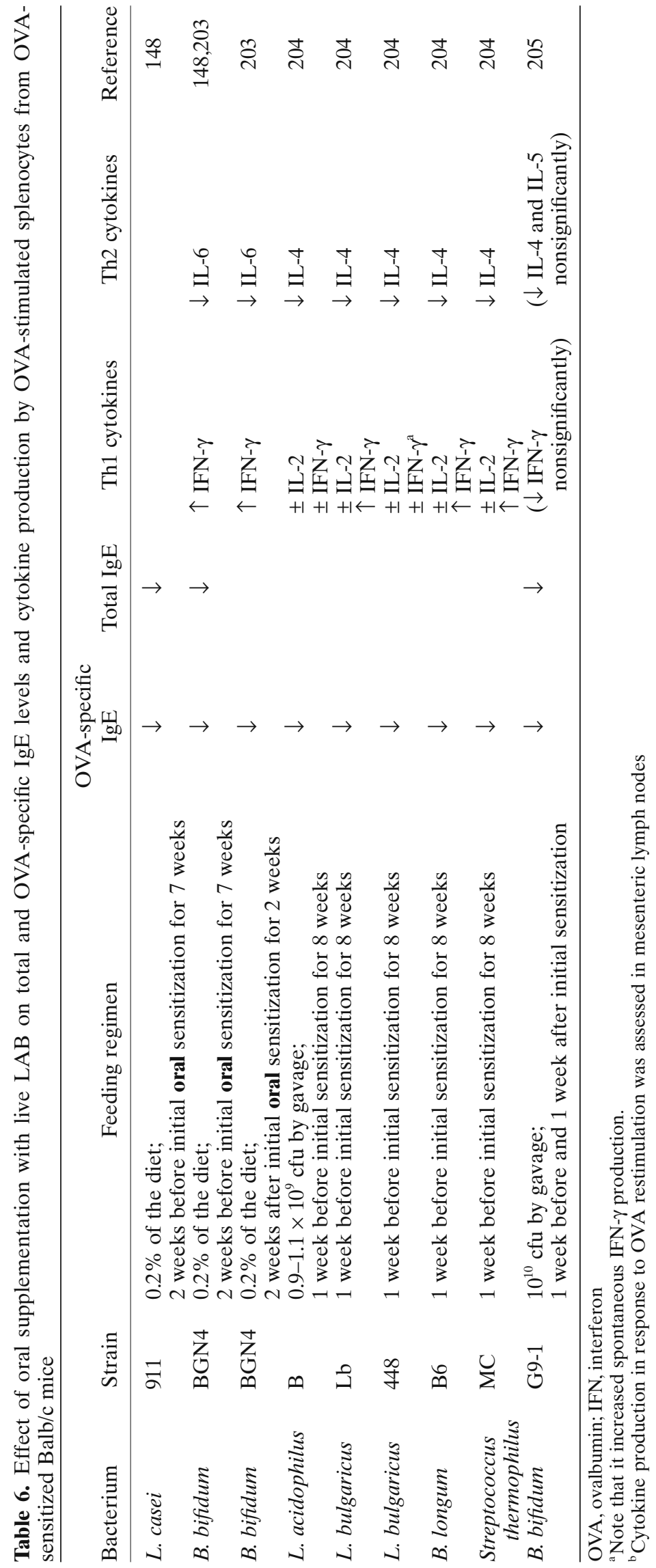


Table 7. Effect of oral supplementation with heat-killed LAB on total and OVA-specific IgE levels and cytokine production by OVA-stimulated splenocytes from OVA-sensitized Balb/c mice

\begin{tabular}{|c|c|c|c|c|c|c|c|}
\hline Bacterium & Strain & Bacterial dose & $\begin{array}{l}\text { Total } \\
\text { IgE }\end{array}$ & $\begin{array}{l}\text { OVA- } \\
\text { specific } \\
\text { IgE }\end{array}$ & $\begin{array}{l}\text { Cytokine } \\
\text { changes }\end{array}$ & & Reference \\
\hline L. acidophilus & L-92 & $\begin{array}{l}5.0 \mathrm{mg} / \text { animal per day; } \\
2 \text { weeks after initial immunization } \\
\quad \text { for } 8 \text { weeks }\end{array}$ & $\downarrow$ & $\downarrow$ & $\downarrow$ IFN- $\gamma$ & $\begin{array}{l}\downarrow \text { IL-4 } \\
\downarrow \text { IL-10 }\end{array}$ & 206 \\
\hline L. brevis & SBC8803 & $\begin{array}{l}0.5 \% \text { of diet; } \\
1 \text { week before initial sensitization } \\
\text { for } 4 \text { weeks }\end{array}$ & $\downarrow$ & $\downarrow$ & $\begin{array}{l}\downarrow \text { IFN- } \gamma \\
\downarrow \text { IL-12 }\end{array}$ & $\begin{array}{l}\downarrow \text { IL-4 } \\
\text { ( } \downarrow \text { IL-5 and IL-6 } \\
\quad \text { nonsignificantly) }\end{array}$ & 207 \\
\hline L. casei & Shirota & $\begin{array}{l}0.1 \text { or } 0.05 \% \text { of the diet; } \\
\text { at initial sensitization for } 3 \text { weeks }\end{array}$ & $\downarrow$ & $\downarrow$ & $\begin{array}{l}\uparrow \mathrm{IFN}-\gamma \\
\uparrow \mathrm{IL}-2\end{array}$ & $\begin{array}{l}\downarrow \text { IL-4 } \\
\downarrow \text { IL-5 } \\
\downarrow \text { IL-6 } \\
\downarrow \text { IL-10 }\end{array}$ & 208 \\
\hline L. gasseri & OLL2809 & $\begin{array}{l}0.1 \% \text { of the diet; } \\
\text { at initial sensitization for } 3 \text { weeks }\end{array}$ & $\downarrow$ & & $\begin{array}{l} \pm \mathrm{IFN}-\gamma \\
\uparrow \mathrm{IL}-12\end{array}$ & $\downarrow$ IL-4 & 178 \\
\hline L. paracasei & KW3110 & $\begin{array}{l}0.03 \% \text { of the diet starting at initial } \\
\text { sensitization for } 14 \text { weeks }\end{array}$ & $\downarrow$ & $\downarrow$ & $\begin{array}{l} \pm \mathrm{IFN}-\gamma \\
\uparrow \mathrm{IL}-12\end{array}$ & $\begin{array}{l}(\downarrow \text { IL-4 } \\
\text { nonsignificantly) }\end{array}$ & 209 \\
\hline L. pentosus & $\begin{array}{l}\text { S-PT84 } \\
\quad \text { (FERM } \\
\text { ABP-1002) }\end{array}$ & $\begin{array}{l}0.075 \% \text { of the diet; } \\
1 \text { week before initial sensitization } \\
\text { for } 5 \text { weeks }\end{array}$ & $\downarrow$ & $\downarrow$ & $\begin{array}{l} \pm \mathrm{IFN}-\gamma \\
\pm \mathrm{IL}-12\end{array}$ & $\begin{array}{l}\downarrow \text { IL-4 } \\
\uparrow \text { IL-10 }\end{array}$ & 210 \\
\hline
\end{tabular}

In one of the few studies to investigate the therapeutic rather than preventative effects of oral LAB supplementation, L. plantarum ATCC 8014 was identified as a strain that strongly induces IL-10 and far less IL-12 in human MDDCs, although the resulting DCs primed naïve allogeneic CD4+ T cells for the production of high levels of IFN- $\gamma$ along with IL-10. ${ }^{145}$ When L. plantarum was used as an adjuvant in sublingual immunotherapy in established murine asthma, airway hyperresponsiveness was significantly reduced compared with phosphate-buffered saline, whereas OVA alone or $L$. plantarum alone only induced nonsignificant reductions. This was not due to effects on OVA-specific IgE titers, the percentage of OVA-specific IL-5-producing splenocytes, or the activity of natural Tregs. Instead, $L$. plantarum markedly increased the proportion of OVA-specific proliferating $\mathrm{T}$ cells in cervical/maxillary lymph nodes. What role, if any, this enhanced proliferation plays in its beneficial effect in this therapeutic asthma model remains to be established.

Few other studies addressed the therapeutic rather than preventative effects of oral LAB administration. In a model of established allergic rhinitis, in which i.p. OVA sensitization and s.c. boosting were followed by intranasal OVA challenge, 3 days of supplementation with L. acidophilus L92 and L. fermentum CP34 were sufficient to significantly reduce allergen-specific $\operatorname{IgE}{ }^{146}$ Milk fermented with these or several other Lactobacillus strains was also effective. In a similar experimental model of allergic rhinitis, but with a longer duration of sensitization and also of probiotic administration, $L$. acidophilus L-55 reduced OVA-specific IgE as measured by passive cutaneous anaphylaxis. ${ }^{147}$ It also less- ened sneezing and nasal rubbing, the effect becoming significant 2 weeks after the beginning of probiotic treatment and lasting throughout the treatment period. In a murine model of food allergy where mice were orally sensitized by intragastric administration of OVA together with cholera toxin, therapeutic administration of B. bifidum BGN4 inhibited OVA-specific IgE production, while increasing IFN- $\gamma$ and decreasing IL-6 secretion by OVA-stimulated splenocytes and diminishing the number of degranulated mast cells in ear and tongue tissue. ${ }^{148}$ These effects were somewhat smaller than those seen after preventative treatment with the same strain, but this may have been due to the much shorter treatment period, which was 2 weeks compared with 7 weeks in the prevention study.

\section{Probiotics in liver diseases and cancer}

Although beyond the aims of the present manuscript, a brief mention of the potential impact of probiotics on chronic liver diseases and cancer is in order.

The effectiveness of lactulose as the only available treatment for encephalopathy in liver cirrhosis has provided a rationale for the use of probiotics in chronic liver diseases. Indeed, this is mostly based on two major mechanisms, that is, the ability to augment the intestinal barrier function and to prevent the translocation of bacteria. ${ }^{149}$ Both mechanisms represent the rationale for the use of probiotics to prevent major complications of liver cirrhosis such as the development of a hyperdynamic circulatory state or spontaneous bacterial peritonitis, with the former being the background for the establishment of portal hypertension. ${ }^{150}$ While solid data 
from human studies are awaited to confirm animal evidence, ${ }^{151}$ the use of probiotics is considered safe in patients with chronic liver diseases, with the possible exception of end-stage functionally impaired liver cirrhosis. Based on the immunomodulatory impact of probiotics, the possibility that these may manifest significant effects on the rapidly growing clinical problem of nonalcoholic fatty liver disease should not be ruled out. ${ }^{152}$

It is well established that the etiopathogenesis of cancer involves several immune-mediated pathways, ${ }^{153}$ particularly in the mucosal epithelia. ${ }^{17,154} \mathrm{~A}$ significant efficacy of probiotics on cancer development is suggested by several lines of scientific evidence and hypotheses, including the increase in immune cell activation and the suppression of bacteria converting procarcinogens. ${ }^{155}$ Most data were obtained from cases of colon and breast carcinomas. In the former, prevention was first achieved in animal models and was ascribed to the significant anti-inflammatory effect of probiotics. ${ }^{156}$ Of note, this is in agreement with data obtained in clinical entities characterized by chronic inflammation and higher carcinoma prevalence such as UC, as previously illustrated. In the case of breast cancer, on the other hand, suggested beneficial effects of probiotics appear to be mediated by an increase of the antitumor surveillance immune activity. ${ }^{157}$ In both cases, however, more solid data are encouraged and awaited in prospective randomized studies of sufficient comparison power. Careful evaluation is also recommended in specific intensive care cases, as strongly suggested by data in patients with severe acute pancreatitis. ${ }^{158}$

\section{Probiotic supplementation in healthy volunteers}

A number of studies have addressed the effects of supplementation with various probiotic strains in healthy volunteers. Increases in NK activity have been observed after supplementation with $L$. casei Shirota ${ }^{159-161} L$. casei DN114001, ${ }^{162}$ L. rhamnosus HN001, ${ }^{163,164}$ or $B$. lactis HN019. ${ }^{164-166}$ Increases in polymorphonuclear and/or macrophage phagocytic activity have also been reported after supplementation with $L$. casei DN114001, ${ }^{162}$ B. lactis HN019, ${ }^{165,166}$ L rhamnosus HN001, ${ }^{163}$ a combination of L. acidophilus 74-2 and B. animalis ssp. lactis $420,{ }^{167}$ or a combination of those two strains with L. paracasei Lpc-37. ${ }^{168}$ Interestingly, a similar mixture, but consisting of different strains $(B$. animalis ssp. lactis Bb-12 and Lactobacillus paracasei ssp. paracasei CRL-431) did not enhance phagocytosis at any of the four doses tested. ${ }^{169}$ The effect size is frequently small and of questionable clinical relevance, although subjects with low innate immune responses may benefit significantly. ${ }^{160,161,166}$

Of note, even though several small studies indicated that $L$. casei Shirota supplementation could increase
NK cell and phagocytic activity, one of the probiotic supplementation studies with the highest methodological quality did not. ${ }^{170}$ In this randomized placebocontrolled trial, all volunteers were kept on a controlled diet throughout the 2-week stabilization, 4-week treatment, and 2-week follow-up, periods. ${ }^{170}$ None of the immune parameters under investigation was significantly affected by supplementation with $L$. casei strain Shirota. Besides NK cell activity, phagocytic, and respiratory burst activity, these included lymphocyte subset distribution, serum levels of $\operatorname{IgM}, \operatorname{IgG}, \operatorname{IgA}$, and $\operatorname{IgE}$, PBMC production of IL-1 $\beta$, IL-2, and IFN- $\gamma$ in response to LPS stimulation, and delayed-type hypersensitivity responses to eight recall antigens.

A few other studies have addressed the ex vivo cytokine production of PBMCs from volunteers who had consumed probiotics, and they generally found few, if any, effects. ${ }^{169,171}$ In contrast, supplementation of volunteers with $L$. fermentum ECET5716 for 2 weeks before and 2 weeks after vaccination with an inactivated trivalent influenza vaccine increased serum IL-12 levels before vaccination, and enhanced vaccine-induced elevations in serum TNF- $\alpha .{ }^{172}$ It also induced significantly higher levels of specific IgA, but not IgG or IgM, compared with the placebo group. Minor adjuvant effects have also been reported for LGG or L. paracasei ssp. paracasei CRL431, ${ }^{173}$ a combination of probiotics (LGG, L. rhamnosus LC705, B. breve Bbi99, and P. freudenreichii ssp. shermanii) plus galactooligosaccharides, ${ }^{174}$ and L. paracasei ssp. paracasei F19. ${ }^{175}$ Overall, these results suggest that several probiotic strains may have the ability to enhance nonspecific immune responses, but the effects on adaptive cellular and humoral immune responses seem to be for the most part minor.

\section{Identification of active probiotics components and receptor usage}

The sometimes identical, sometimes differential effects of viable and nonviable bacteria suggest that metabolic or secreted factors as well as structural or other cellular components mediate certain immunomodulatory activities of probiotics ${ }^{47,139,176}$ (Tables 3, 4, 6, and 7). But the viability requirement depends not only on the immunomodulatory function under investigation but also on the bacterial strain. ${ }^{44,177}$ This suggests, and other data confirm, ${ }^{178}$ that even members of the same species differ substantially in their composition or their production of secreted mediators. Various experiments indicate that the ability to induce the secretion of various cytokines is mediated to a large extent by cell wall components. ${ }^{177,179,180}$ In particular, peptidoglycans have been implicated in IL-12 induction in splenocytes, ${ }^{178}$ while lipoteichoic acids are involved in the stimulation of 
Table 8. Involvement of TLR-2, -4, -9, and the adaptor molecule MyD88 in probiotic activities

\begin{tabular}{|c|c|c|c|c|c|c|c|}
\hline Bacterium & Strain & Activity & TLR2 & TLR4 & TLR9 & MyD88 & Reference \\
\hline L. casei & NIZO B255 & Luciferase reporter in HEK-23 cells & - & - & - & & $39 a$ \\
\hline L. plantarum & NIZO B253 & Luciferase reporter in HEK-23 cells & - & - & - & & \\
\hline L. reuteri & ASM 20016 & Luciferase reporter in HEK-23 cells & - & - & - & & \\
\hline L. acidophilus & L-2 & $\begin{array}{l}\text { IL- } 12 \text { production in Peyer's patch and } \\
\text { BMDCs from mice deficient in the } \\
\text { respective TLR }\end{array}$ & - & - & - & + & 190 \\
\hline L. casei & Shirota & $\begin{array}{l}\text { IL- } 12 \text { production in macrophages from mice } \\
\text { deficient in the respective TLR }\end{array}$ & - & - & - & + & 190 \\
\hline L. johnsonii & La1 & & - & - & - & + & \\
\hline L. paracasei & KW3110 & & - & - & - & + & \\
\hline L. rhamnosus & GG & & - & - & - & + & \\
\hline L. casei & Shirota & & - & - & & + & 180 \\
\hline L. casei & ATCC 334 & & - & - & & + & \\
\hline L. fermentum & ATCC 14931 & & - & - & & + & \\
\hline L. rhamnosus & ATCC 7469 & & - & - & & + & \\
\hline $\begin{array}{l}\text { L. plantarum } \\
\text { UV-killed }\end{array}$ & Unspecified & $\begin{array}{l}\text { TNF- } \alpha \text { production of human macrophages } \\
\text { in the presence of anti-TLR } 2 \text { or anti- } \\
\text { TLR } 4 \text { antibodies }\end{array}$ & ++ & \pm & & & 189 \\
\hline \multirow[t]{2}{*}{ L. plantarum } & NCIMB 8826 & $\begin{array}{l}\text { IL- } 10 \text { production by BMDCs of mice } \\
\text { deficient in the respective TLR or MyD } 88\end{array}$ & + & - & & + & 211 \\
\hline & & $\begin{array}{l}\text { IL- } 12 \text { production by BMDCs of mice } \\
\text { deficient in the respective TLR or MyD } 88\end{array}$ & \pm & - & & \pm & 211 \\
\hline $\begin{array}{l}\text { B. animalis ssp. } \\
\text { lactis }\end{array}$ & Bb-12 & $\begin{array}{l}\text { IL-6 production in mouse embryonic } \\
\text { fibroblasts from TLR2-deficient mice }\end{array}$ & + & & & & 212 \\
\hline $\begin{array}{l}\text { B. animalis ssp. } \\
\text { lactis }\end{array}$ & Bb-12 & $\begin{array}{l}\text { IL-1b production in mouse embryonic } \\
\text { fibroblasts from TLR2-deficient mice }\end{array}$ & - & & & & 212 \\
\hline
\end{tabular}

TLR, Toll-like receptor; TNF, tumor necrosis factor

${ }^{a}$ They also did not activate TLR1, -6 , or -7

TNF- $\alpha$ production in macrophages and splenocytes. ${ }^{181}$ In addition, DNA has been shown to mediate a variety of immunomodulatory effects of certain probiotic strains both in vitro and in vivo. ${ }^{48,113,177}$ Note that ISS-DNA sequences have been identified in a variety of probiotic strains, including LGG, ${ }^{182}$ Lactobacillus delbrueckii ssp. bulgaricus NIAI B6, ${ }^{183}$ Lactobacillus gasseri OLL2716, ${ }^{184}$ and B. longum BB536. ${ }^{185}$ The ISS-ODN from B. longum BB536 and LGG exhibited immunomodulatory activity in OVA-immunized mice after oral and i.p. administration, respectively. ${ }^{186,187}$

Recognition of bacteria is mediated by a variety of pattern recognition receptors, the most important of which are TLRs and nucleotide-binding oligomerization domain (NOD) proteins. TLR usage by LAB strains is species- as well as activity-specific (see Table 8), probably partly attributable to the considerable variation in the cell wall composition even of members of the same species. ${ }^{178}$ The TLRs identified as mediating certain activities of probiotics include TLR2, TLR9, and NOD $2^{188}$ (see Table 8 ). Their ligands are peptidoglycans and lipoteichoic acid from Gram-positive bacteria in the case of TLR2, and CpG DNA in the case of TLR9, while NOD2 recognizes muramyl dipeptide, a constituent of peptidoglycans from both Gram-positive and Gram- negative bacteria. This further supports an important role for cell wall components and DNA in the immunomodulatory activities of probiotics. TLR 4 recognizes LPS of Gram-negative bacteria, and its implication in macrophage TNF- $\alpha$ production in response to L. plantarum $^{189}$ is therefore unexpected. Note that some in vitro and in vivo effects of probiotics were found not to require TLR2, TLR4, or TLR9. ${ }^{107,180,190}$ However, deficiency of MyD88, an adapter molecule for TLR signaling, abolished the investigated activities. It remains to be established whether other TLRs or a MyD88-dependent, but TLR-independent, pathway is involved.

\section{Final comments and thoughts}

While there is substantial evidence from in vitro and animal studies that known and potential probiotics have strain-specific immunomodulatory capacities, the results from human intervention trials are far less convincing. This may be partly a question of the dose, which is often similar in animal studies and human trials despite the enormous difference in weight and intestinal size. Dose-response studies are urgently required, especially 
since there are indications that certain in vitro effects are seen only at low bacterial doses ${ }^{39}$ and that high doses may produce opposite effects to those obtained at low doses. ${ }^{47}$ The results of a human supplementation trial also suggest that lower doses can be more effective than higher doses. ${ }^{166}$ It might be advisable to determine whether a probiotic has any effect and whether it retains this effect when used in combination with another probiotic before proceeding with a dose-response study that ultimately shows that a probiotic combination has no effect at four different doses. ${ }^{169}$

Another potential explanation for the differential effectiveness of probiotics in animals and humans might be that the composition of the intestinal microflora is likely to vary to a much greater extent between individual humans than between individual mice that are kept in the same environment and fed the same diet. Since in vitro studies suggest considerable interactions between different commensal and probiotic strains, ${ }^{30,31}$ human responses to probiotic treatment might differ depending on the composition of the individual's endogenous flora. Genetic differences in the expression of pattern recognition receptors and other factors contributing to the response to bacterial signals are also likely to contribute to the variable responses to probiotic treatment.

Despite the mostly minor immunomodulatory effects of probiotics in human supplementation studies, there are some concerning findings, such as the increased rate of sensitization or greater frequency of wheezing in participants of primary intervention trials who received L. acidophilus LAVRI-A1 or LGG ${ }^{119,143}$ or the more severe endoscopic recurrence seen in $\mathrm{CD}$ patients treated with LGG. ${ }^{89}$ Note also that there is some concern that strongly Th1-promoting strains may aggravate Th1-mediated autoimmune diseases. There are several studies showing the exacerbation of experimental autoimmune encephalomyelitis (EAE), a Th1-mediated model of multiple sclerosis, with certain Lactobacillus strains, including the well-established probiotic L. casei Shirota. ${ }^{191-193}$ However, other probiotic strains are capable of ameliorating EAE,${ }^{194}$ and other experimental autoimmune diseases that are known to be Th1 mediated, such as various models of rheumatoid arthritis ${ }^{195-197}$ or type 1 diabetes. ${ }^{198}$ Together, these findings highlight the need for care in choosing appropriate probiotic strains for particular applications. In this process, it needs to be taken into account that the response to probiotic supplementation depends on the immunological status of the host, as demonstrated by in vitro ${ }^{98,199}$ and in vivo experiments. ${ }^{168,200}$ What ultimately counts in the search for functional foods to modulate the immune response is that well-tolerated and effective nutrients are needed, and probiotics are currently among the best candidates to play this critical role in future epidemics of metabolic and inflammatory conditions.

\section{References}

1. Hahn BH, Grossman J, Chen W, McMahon M. The pathogenesis of atherosclerosis in autoimmune rheumatic diseases: roles of inflammation and dyslipidemia. J Autoimmun 2007;28:6975 .

2. Blank M, Gershwin ME. Autoimmunity: from the mosaic to the kaleidoscope. J Autoimmun 2008;30:1-4.

3. Escarcega RO, Garcia-Carrasco M, Fuentes-Alexandro S, Jara LJ, Rojas-Rodriguez J, Escobar-Linares LE, et al. Insulin resistance, chronic inflammatory state and the link with systemic lupus erythematosus-related coronary disease. Autoimmun Rev 2006;6:48-53.

4. Belizna CC, Richard V, Thuillez C, Levesque H, Shoenfeld Y. Insights into atherosclerosis therapy in antiphospholipid syndrome. Autoimmun Rev 2007;7:46-51.

5. Food and Agriculture Organization of the United Nations, World Health Organization. Guidelines for evaluation of probiotics in food. London, Ontario: Canada; 2002. ftp://ftp.fao.org/ es/esn/food/wgreport2.pdf, accessed 18 April 2008.

6. Mowat AM. Anatomical basis of tolerance and immunity to intestinal antigens. Nat Rev Immunol 2003;3:331-41.

7. Rescigno M, Urbano M, Valzasina B, Francolini M, Rotta G, Bonasio R, et al. Dendritic cells express tight junction proteins and penetrate gut epithelial monolayers to sample bacteria. Nat Immunol 2001;2:361-7.

8. Niess JH, Brand S, Gu X, Landsman L, Jung S, McCormick BA, et al. $\mathrm{CX}_{3} \mathrm{CR} 1-$ mediated dendritic cell access to the intestinal lumen and bacterial clearance. Science 2005;307:254-8.

9. Chieppa M, Rescigno M, Huang AY, Germain RN. Dynamic imaging of dendritic cell extension into the small bowel lumen in response to epithelial cell TLR engagement. J Exp Med 2006;203:2841-52.

10. Steffen EK, Berg RD. Relationship between cecal population levels of indigenous bacteria and translocation to the mesenteric lymph nodes. Infect Immun 1983;39:1252-9.

11. Ibnou-Zekri N, Blum S, Schiffrin EJ, von der Weid T. Divergent patterns of colonization and immune response elicited from two intestinal Lactobacillus strains that display similar properties in vitro. Infect Immun 2003;71:428-36.

12. Macpherson AJ, Uhr T. Induction of protective IgA by intestinal dendritic cells carrying commensal bacteria. Science 2004;303: 1662-5.

13. Banchereau J, Briere F, Caux C, Davoust J, Lebecque S, Liu YJ, et al. Immunobiology of dendritic cells. Annu Rev Immunol 2000;18:767-811.

14. Bilsborough J, Viney JL. Gastrointestinal dendritic cells play a role in immunity, tolerance, and disease. Gastroenterology 2004;127:300-9.

15. Steinman RM, Hawiger D, Nussenzweig MC. Tolerogenic dendritic cells. Annu Rev Immunol 2003;21:685-711.

16. Peng Y, Martin DA, Kenkel J, Zhang K, Ogden CA, Elkon KB. Innate and adaptive immune response to apoptotic cells. J Autoimmun 2007;29:303-9.

17. Lan RY, Mackay IR, Gershwin ME. Regulatory T cells in the prevention of mucosal inflammatory diseases: patrolling the border. J Autoimmun 2007;29:272-80.

18. Bamias G, Okazawa A, Rivera-Nieves J, Arseneau KO, De La Rue SA, Pizarro TT, et al. Commensal bacteria exacerbate intestinal inflammation but are not essential for the development of murine ileitis. J Immunol 2007;178:1809-18.

19. Liu Z, Jiu J, Liu S, Fa X, Li F, Du Y. Blockage of tumor necrosis factor prevents intestinal mucosal inflammation through downregulation of interleukin-23 secretion. J Autoimmun 2007;29: 187-94.

20. Nakagome Y, Ueno Y, Kogure T, Fukushima K, Moritoki Y, Ridgway WM, et al. Autoimmune cholangitis in NOD.c3c4 mice is associated with cholangiocyte-specific Fas antigen deficiency. J Autoimmun 2007;29:20-9. 
21. Glaysher BR, Mabbott NA. Role of the GALT in scrapie agent neuroinvasion from the intestine. J Immunol 2007;178:3757-66.

22. Song F, Wardrop RM, Gienapp IE, Stuckman SS, Meyer AL, Shawler T, et al. The Peyer's patch is a critical immunoregulatory site for mucosal tolerance in experimental autoimmune encephalomylelitis (EAE). J Autoimmun 2008;30:230-7.

23. Kristof K, Erdei A, Bajtay Z. Set a thief to catch a thief: selfreactive innate lymphocytes and self tolerance. Autoimmun Rev 2008;7:278-83.

24. Wan EC, Gordon TP, Jackson MW. Autoantibodies to calcium channels in type 1 diabetes mediate autonomic dysfunction by different mechanisms in colon and bladder and are neutralized by antiidiotypic antibodies. J Autoimmun 2008;31:66-72.

25. Briani C, Samaroo D, Alaedini A. Celiac disease: from gluten to autoimmunity. Autoimmun Rev 2008.

26. O'Mahony L, O'Callaghan L, McCarthy J, Shilling D, Scully P, Sibartie S, et al. Differential cytokine response from dendritic cells to commensal and pathogenic bacteria in different lymphoid compartments in humans. Am J Physiol Gastrointest Liver Physiol 2006;290:G839-45.

27. Hart AL, Lammers K, Brigidi P, Vitali B, Rizzello F, Gionchetti $\mathrm{P}$, et al. Modulation of human dendritic cell phenotype and function by probiotic bacteria. Gut 2004;53:1602-9.

28. Fink LN, Zeuthen LH, Ferlazzo G, Frøkiær H. Human antigenpresenting cells respond differently to gut-derived probiotic bacteria but mediate similar strain-dependent NK and $\mathrm{T}$ cell activation. FEMS Immunol Med Microbiol 2007;51:535-46.

29. Young SL, Simon MA, Baird MA, Tannock GW, Bibiloni R, Spencely K, et al. Bifidobacterial species differentially affect expression of cell surface markers and cytokines of dendritic cells harvested from cord blood. Clin Diagn Lab Immunol 2004; 11:686-90.

30. Zeuthen LH, Christensen HR, Frøkiær H. Lactic acid bacteria inducing a weak interleukin-12 and tumor necrosis factor alpha response in human dendritic cells inhibit strongly stimulating lactic acid bacteria but act synergistically with Gram-negative bacteria. Clin Vaccine Immunol 2006;13:365-75.

31. Fink LN, Zeuthen LH, Christensen HR, Morandi B, Frøkiær H, Ferlazzo G. Distinct gut-derived lactic acid bacteria elicit divergent dendritic cell-mediated NK cell responses. Int Immunol 2007;19:1319-27.

32. Gackowska L, Michalkiewicz J, Krotkiewski M, Helmin-Basa A, Kubiszewska I, Dzierzanowska D. Combined effect of different lactic acid bacteria strains on the mode of cytokines pattern expression in human peripheral blood mononuclear cells. J Physiol Pharmacol 2006;57 Suppl 9:13-21.

33. Kekkonen RA, Kajasto E, Miettinen M, Veckman V, Korpela R, Julkunen I. Probiotic Leuconostoc mesenteroides ssp. cremoris and Streptococcus thermophilus induce IL-12 and IFN-g production. World J Gastroenterol 2008;14:1192-203.

34. Mohamadzadeh M, Olson S, Kalina WV, Ruthel G, Demmin GL, Warfield KL, et al. Lactobacilli activate human dendritic cells that skew T cells toward T helper 1 polarization. Proc Natl Acad Sci USA 2005;102:2880-5.

35. Braat H, de Jong EC, van den Brande JM, Kapsenberg ML, Peppelenbosch MP, van Tol EA, et al. Dichotomy between Lactobacillus rhamnosus and Klebsiella pneumoniae on dendritic cell phenotype and function. J Mol Med 2004;82:197-205.

36. Drakes M, Blanchard T, Czinn S. Bacterial probiotic modulation of dendritic cells. Infect Immun 2004;72:3299-309.

37. Niers LE, Hoekstra MO, Timmerman HM, van Uden NO, de Graaf PM, Smits HH, et al. Selection of probiotic bacteria for prevention of allergic diseases: immunomodulation of neonatal dendritic cells. Clin Exp Immunol 2007;149:344-52.

38. Braat $\mathrm{H}$, van den Brande $\mathrm{J}$, van Tol E, Hommes $\mathrm{D}$, Peppelenbosch M, van Deventer S. Lactobacillus rhamnosus induces peripheral hyporesponsiveness in stimulated $\mathrm{CD}^{+} \mathrm{T}$ cells via modulation of dendritic cell function. Am J Clin Nutr 2004;80:1618-25.
39. Smits HH, Engering A, van der Kleij D, de Jong EC, Schipper K, van Capel TM, et al. Selective probiotic bacteria induce IL-10producing regulatory $\mathrm{T}$ cells in vitro by modulating dendritic cell function through dendritic cell-specific intercellular adhesion molecule 3-grabbing nonintegrin. J Allergy Clin Immunol 2005;115:1260-7.

40. von der Weid T, Bulliard C, J. SE. Induction by a lactic acid bacterium of a population of $\mathrm{CD} 4^{+} \mathrm{T}$ cells with low proliferative capacity that produce transforming growth factor $\mathrm{b}$ and interleukin-10. Clin Diagn Lab Immunol 2001;8:695-701.

41. Rimoldi M, Chieppa M, Larghi P, Vulcano M, Allavena P, Rescigno M. Monocyte-derived dendritic cells activated by bacteria or by bacteria-stimulated epithelial cells are functionally different. Blood 2005;106:2818-26.

42. Zeuthen LH, Fink LN, Frøkiær H. Epithelial cells prime the immune response to an array of gut-derived commensals towards a tolerogenic phenotype through distinct actions of thymic stromal lymphopoietin and transforming growth factor- $\beta$. Immunology 2008;123:197-208.

43. Roselli M, Finamore A, Britti MS, Mengheri E. Probiotic bacteria Bifidobacterium animalis MB5 and Lactobacillus rhamnosus GG protect intestinal Caco-2 cells from the inflammationassociated response induced by enterotoxigenic Escherichia coli K88. Br J Nutr 2006;95:1177-84.

44. Morita H, He F, Fuse T, Ouwehand AC, Hashimoto H, Hosoda $\mathrm{M}$, et al. Adhesion of lactic acid bacteria to Caco-2 cells and their effect on cytokine secretion. Microbiol Immunol 2002;46: 293-7.

45. Otte JM, Podolsky DK. Functional modulation of enterocytes by Gram-positive and Gram-negative microorganisms. Am J Physiol Gastrointest Liver Physiol 2004;286:G613-26.

46. O'Hara AM, O'Regan P, Fanning A, O'Mahony C, Macsharry J, Lyons A, et al. Functional modulation of human intestinal epithelial cell responses by Bifidobacterium infantis and Lactobacillus salivarius. Immunology 2006;118:202-15.

47. Zhang L, Li N, Caicedo R, Neu J. Alive and dead Lactobacillus rhamnosus GG decrease tumor necrosis factor-alpha-induced interleukin-8 production in Caco-2 cells. J Nutr 2005;135: $1752-6$.

48. Jijon H, Backer J, Diaz H, Yeung H, Thiel D, McKaigney C, et al. DNA from probiotic bacteria modulates murine and human epithelial and immune function. Gastroenterology 2004; 126:1358-73.

49. Haller D, Bode C, Hammes WP, Pfeifer AM, Schiffrin EJ, Blum S. Non-pathogenic bacteria elicit a differential cytokine response by intestinal epithelial cell/leucocyte co-cultures. Gut 2000;47: $79-87$.

50. Rimoldi M, Chieppa M, Salucci V, Avogadri F, Sonzogni A, Sampietro GM, et al. Intestinal immune homeostasis is regulated by the crosstalk between epithelial cells and dendritic cells. Nat Immunol 2005;6:507-14.

51. Li HS, Ligons DL, Rose NR. Genetic complexity of autoimmune myocarditis. Autoimmun Rev 2008;7:168-73.

52. Baschal EE, Eisenbarth GS. Extreme genetic risk for type $1 \mathrm{~A}$ diabetes in the post-genome era. J Autoimmun 2008;31:1-6.

53. Gleicher N, Barad DH. Gender as risk factor for autoimmune diseases. J Autoimmun 2007;28:1-6.

54. Jordan MA, Baxter AG. The genetics of immunoregulatory T cells. J Autoimmun 2008.

55. Rieger $\mathrm{R}$, Gershwin ME. The $\mathrm{X}$ and why of xenobiotics in primary biliary cirrhosis. J Autoimmun 2007;28:76-84.

56. Smith P, Mangan NE, Walsh CM, Fallon RE, McKenzie AN, van Rooijen N, et al. Infection with a helminth parasite prevents experimental colitis via a macrophage-mediated mechanism. J Immunol 2007;178:4557-66.

57. Frazer IH. Autoimmunity and persistent viral infection: two sides of the same coin? J Autoimmun 2008.

58. Praprotnik S, Sodin-Semrl S, Tomsic M, Shoenfeld Y. The curiously suspicious: infectious disease may ameliorate an ongoing 
autoimmune destruction in systemic lupus erythematosus patients. J Autoimmun 2008;30:37-41.

59. Stojanovich L, Marisavljevich D. Stress as a trigger of autoimmune disease. Autoimmun Rev 2008;7:209-13.

60. Tozzoli R, Barzilai O, Ram M, Villalta D, Bizzaro N, Sherer Y, et al. Infections and autoimmune thyroid diseases: parallel detection of antibodies against pathogens with proteomic technology. Autoimmun Rev 2008 Aug 9 [Epub ahead of print].

61. Sheasley-O'Neill SL, Brinkman CC, Ferguson AR, Dispenza MC, Engelhard VH. Dendritic cell immunization route determines integrin expression and lymphoid and nonlymphoid tissue distribution of CD8 T cells. J Immunol 2007;178:1512-22.

62. Abbas AK, Lohr J, Knoechel B. Balancing autoaggressive and protective T cell responses. J Autoimmun 2007;28:59-61.

63. Atzeni F, Doria A, Carrabba M, Turiel M, Sarzi-Puttini P Potential target of infliximab in autoimmune and inflammatory diseases. Autoimmun Rev 2007;6:529-36.

64. Lleo A, Invernizzi P, Selmi C, Coppel RL, Alpini G, Podda M, et al. Autophagy: highlighting a novel player in the autoimmunity scenario. J Autoimmun 2007;29:61-8.

65. Bai AP, Ouyang Q, Xiao XR, Li SF. Probiotics modulate inflammatory cytokine secretion from inflamed mucosa in active ulcerative colitis. Int J Clin Pract 2006;60:284-8.

66. Rachmilewitz D, Karmeli F, Shteingart S, Lee J, Takabayashi K, Raz E. Immunostimulatory oligonucleotides inhibit colonic proinflammatory cytokine production in ulcerative colitis. Inflamm Bowel Dis 2006;12:339-45.

67. Borruel N, Casellas F, Antolín M, Llopis M, Carol M, Espíin E, et al. Effects of nonpathogenic bacteria on cytokine secretion by human intestinal mucosa. Am J Gastroenterol 2003;98:86570.

68. Borruel N, Carol M, Casellas F, Antolín M, de Lara F, Espín E, et al. Increased mucosal tumour necrosis factor a production in Crohn's disease can be downregulated ex vivo by probiotic bacteria. 51 2002;5.

69. Carol M, Borruel N, Antolín M, Llopis M, Casellas F, Guarner $\mathrm{F}$, et al. Modulation of apoptosis in intestinal lymphocytes by a probiotic bacteria in Crohn's disease. J Leukoc Biol 2006; 79:917-22.

70. Ardesjo B, Hansson CM, Bruder CE, Rorsman F, Betterle C, Dumanski JP, et al. Autoantibodies to glutathione $S$-transferase theta 1 in patients with primary sclerosing cholangitis and other autoimmune diseases. J Autoimmun 2008;30:273-82.

71. Reinecker HC, Steffen M, Witthoeft T, Pflueger I, Schreiber S, MacDermott RP, et al. Enhanced secretion of tumour necrosis factor-alpha, IL- 6 , and IL- $1 \beta$ by isolated lamina propria mononuclear cells from patients with ulcerative colitis and Crohn's disease. Clin Exp Immunol 1993;94:174-81.

72. Atreya R, Mudter J, Finotto S, Müllberg J, Jostock T, Wirtz S, et al. Blockade of interleukin 6 trans signaling suppresses T-cell resistance against apoptosis in chronic intestinal inflammation: evidence in Crohn disease and experimental colitis in vivo. Nat Med 2000;6:583-8.

73. Jonkers D, R. S. Review article: probiotics in gastrointestinal and liver diseases. Aliment Pharmacol Ther 2007;26 Suppl 2:133-48.

74. Holmén N, Lundgren A, Lundin S, Bergin AM, Rudin A, Sjövall $\mathrm{H}$, et al. Functional $\mathrm{CD} 4^{+} \mathrm{CD} 25^{\text {high }}$ regulatory $\mathrm{T}$ cells are enriched in the colonic mucosa of patients with active ulcerative colitis and increase with disease activity. Inflamm Bowel Dis 2006;12: $447-56$.

75. Saruta M, Yu QT, Fleshner PR, Mantel PY, Schmidt-Weber CB, Banham $\mathrm{AH}$, et al. Characterization of $\mathrm{FOXP}^{+} \mathrm{CD} 4^{+}$regulatory T cells in Crohn's disease. Clin Immunol 2007;125:281-90.

76. Yu QT, Saruta M, Avanesyan A, Fleshner PR, Banham AH, Papadakis KA. Expression and functional characterization of $\mathrm{FOXP}^{+} \mathrm{CD}^{+}$regulatory $\mathrm{T}$ cells in ulcerative colitis. Inflamm Bowel Dis 2007;13:191-9.
77. Sitohy B, Hammarström S, Danielsson A, Hammarström ML. Basal lymphoid aggregates in ulcerative colitis colon: a site for regulatory T cell action. Clin Exp Immunol 2008;151:326-33.

78. Muratov V, Ulfgren AK, Engström M, Elvin K, Winqvist O, Löfberg R, et al. Decreased numbers of FoxP3-positive and TLR-2-positive cells in intestinal mucosa are associated with improvement in patients with active inflammatory bowel disease following selective leukocyte apheresis. J Gastroenterol 2008; 43:277-82.

79. Shaoul R, Lerner A. Associated autoantibodies in celiac disease. Autoimmun Rev 2007;6:559-65.

80. Burek CL, Rose NR. Autoimmune thyroiditis and ROS. Autoimmun Rev 2008;7:530-7.

81. Crane FL, Low H. Reactive oxygen species generation at the plasma membrane for antibody control. Autoimmun Rev 2008; 7:518-22.

82. Davies AJ. Immunological tolerance and the autoimmune response. Autoimmun Rev 2008;7:538-43.

83. Dimitrov JD, Vassilev TL, Andre S, Kaveri SV, LacroixDesmazes S. Functional variability of antibodies upon oxidative processes. Autoimmun Rev 2008;7:574-578.

84. Griffiths HR. Is the generation of neo-antigenic determinants by free radicals central to the development of autoimmune rheumatoid disease? Autoimmun Rev 2008;7:544-9.

85. Kurien BT, Scofield RH. Autoimmunity and oxidatively modified autoantigens. Autoimmun Rev 2008;7:567-73.

86. Ortona E, Margutti P, Matarrese P, Franconi F, Malorni W. Redox state, cell death and autoimmune diseases: a gender perspective. Autoimmun Rev 2008;7:579-84.

87. Salunga TL, Cui ZG, Shimoda S, Zheng HC, Nomoto K, Kondo $\mathrm{T}$, et al. Oxidative stress-induced apoptosis of bile duct cells in primary biliary cirrhosis. J Autoimmun 2007;29:78-86.

88. Sasaki M, Ikeda H, Nakanuma Y. Activation of ATM signaling pathway is involved in oxidative stress-induced expression of mito-inhibitory p21WAF1/Cip1 in chronic non-suppurative destructive cholangitis in primary biliary cirrhosis: an immunohistochemical study. J Autoimmun 2008;31:73-8.

89. Rolfe VE, Fortun PJ, Hawkey CJ, Bath-Hextall F. Probiotics for maintenance of remission in Crohn's disease. Cochrane Database Syst Rev 2006 Oct 18;(4):CD004826.

90. Mallon P, McKay D, Kirk S, Gardiner K. Probiotics for induction of remission in ulcerative colitis. Cochrane Database Syst Rev 2007 Oct 17;(4):CD005573.

91. Zigra PI, Maipa VE, Alamanos YP. Probiotics and remission of ulcerative colitis: a systematic review. Neth J Med 2007;65: 411-8.

92. Furrie E, Macfarlane S, Kennedy A, Cummings JH, Walsh SV, O'Neil DA, et al. Synbiotic therapy (Bifidobacterium longum/ Synergy 1) initiates resolution of inflammation in patients with active ulcerative colitis: a randomised controlled pilot trial. Gut 2005;54:242-9.

93. Ulisse S, Gionchetti P, D'Alò S, Russo FP, Pesce I, Ricci G, et al. Expression of cytokines, inducible nitric oxide synthase, and matrix metalloproteinases in pouchitis: effects of probiotic treatment. Am J Gastroenterol 2001;96:2691-9.

94. O'Mahony L, McCarthy J, Kelly P, Hurley G, Luo F, Chen K, et al. Lactobacillus and Bifidobacterium in irritable bowel syndrome: symptom responses and relationship to cytokine profiles. Gastroenterology 2005;128:541-51.

95. Lorea Baroja M, Kirjavainen PV, Hekmat S, Reid G. Anti-inflammatory effects of probiotic yogurt in inflammatory bowel disease patients. Clin Exp Immunol 2007;149:470-9.

96. Pronio A, Montesani C, Butteroni C, Vecchione S, Mumolo G, Vestri A, et al. Probiotic administration in patients with ileal pouch-anal anastomosis for ulcerative colitis is associated with expansion of mucosal regulatory cells. Inflamm Bowel Dis 2008; $14: 662-8$.

97. Schultz M, Linde HJ, Lehn N, Zimmermann K, Grossmann J, Falk W, et al. Immunomodulatory consequences of oral 
administration of Lactobacillus rhamnosus strain GG in healthy volunteers. J Dairy Res 2003;70:165-73.

98. Hvas CL, Kelsen J, Agnholt J, Höllsberg P, Tvede M, Møller JK, et al. Crohn's disease intestinal CD4+ T cells have impaired interleukin-10 production which is not restored by probiotic bacteria. Scand J Gastroenterol 2007;42:592-601.

99. Mudter J, Wirtz S, Galle PR, Neurath MF. A new model of chronic colitis in SCID mice induced by adoptive transfer of CD62L+CD4+ T cells: insights into the regulatory role of interleukin-6 on apoptosis. Pathobiology 2002-2003;70:170-6.

100. Peran L, Camuesco D, Comalada M, Bailon E, Henriksson A, Xaus J, et al. A comparative study of the preventative effects exerted by three probiotics, Bifidobacterium lactis, Lactobacillus casei and Lactobacillus acidophilus, in the TNBS model of rat colitis. J Appl Microbiol 2007;103:836-44.

101. Peran L, Sierra S, Comalada M, Lara-Villoslada F, Bailón E, Nieto Á, et al. A comparative study of the preventative effects exerted by two probiotics, Lactobacillus reuteri and Lactobacillus fermentum, in the trinitrobenzenesulfonic acid model of rat colitis. Br J Nutr 2007;97:96-103.

102. Dieleman LA, Goerres MS, Arends A, Sprengers D, Torrice C, Hoentjen F, et al. Lactobacillus GG prevents recurrence of colitis in HLA-B27 transgenic rats after antibiotic treatment. Gut 2003;52:370-6.

103. McCarthy J, O'Mahony L, O'Callaghan L, Sheil B, Vaughan EE, Fitzsimons N, et al. Double blind, placebo controlled trial of two probiotic strains in interleukin 10 knockout mice and mechanistic link with cytokine balance. Gut 2003;52:975-80.

104. Schultz M, Veltkamp C, Dieleman LA, Grenther WB, Wyrick PB, Tonkonogy SL, et al. Lactobacillus plantarum $299 \mathrm{~V}$ in the treatment and prevention of spontaneous colitis in interleukin-10deficient mice. Inflamm Bowel Dis 2002;8:71-80.

105. Schultz M, Strauch UG, Linde HJ, Watzl S, Obermeier F, Göttl C, et al. Preventive effects of Escherichia coli strain Nissle 1917 on acute and chronic intestinal inflammation in two different murine models of colitis. Clin Diagn Lab Immunol 2004;11: 372-8.

106. Møller PL, Pærregaard A, Gad M, Kristensen NN, Claesson MH. Colitic SCID mice fed Lactobacillus spp. show an ameliorated gut histopathology and an altered cytokine profile by local T cells. Inflamm Bowel Dis 2005;11:814-9.

107. Foligne B, Zoumpopoulou G, Dewulf J, Ben Younes A, Chareyre F, Sirard JC, et al. A key role of dendritic cells in probiotic functionality. PLoS ONE 2007;2:e313; accessed 18 Apr 2008.

108. Foligne B, Nutten S, Grangette C, Dennin V, Goudercourt D, Poiret $S$, et al. Correlation between in vitro and in vivo immunomodulatory properties of lactic acid bacteria. World J Gastroenterol 2007;13:236-43.

109. Zoumpopoulou G, Foligne B, Christodoulou K, Grangette C, Pot B, Tsakalidou E. Lactobacillus fermentum ACA-DC 179 displays probiotic potential in vitro and protects against trinitrobenzene sulfonic acid (TNBS)-induced colitis and Salmonella infection in murine models. Int J Food Microbiol 2008;121: $18-26$.

110. Grangette C, Nutten S, Palumbo E, Morath S, Hermann C, Dewulf J, et al. Enhanced antiinflammatory capacity of a Lactobacillus plantarum mutant synthesizing modified teichoic acids. Proc Natl Acad Sci USA 2005;102:10321-6.

111. Di Giacinto C, Marinaro M, Sanchez M, Strober W, Boirivant M. Probiotics ameliorate recurrent Th1-mediated murine colitis by inducing IL-10 and IL-10-dependent TGF-b-bearing regulatory cells. J Immunol 2005;174:3237-46.

112. Joetham A, Takeda K, Taube C, Miyahara N, Matsubara S, Koya $\mathrm{T}$, et al. Naturally occurring lung $\mathrm{CD} 4^{+} \mathrm{CD} 25^{+} \mathrm{T}$ cell regulation of airway allergic responses depends on IL-10 induction of TGF- $\beta$. J Immunol 2007;178:1433-42.

113. Rachmilewitz D, Katakura K, Karmeli F, Hayashi T, Reinus C, Rudensky B, et al. Toll-like receptor 9 signaling mediates the anti-inflammatory effects of probiotics in murine experimental colitis. Gastroenterology 2004;126:520-8.

114. Katakura K, Lee J, Rachmilewitz D, Li G, Eckmann L, Raz E. Toll-like receptor 9-induced type I IFN protects mice from experimental colitis. J Clin Invest 2005;115:695-702.

115. Mantovani A, Garlanda C, Locati M, Rodriguez TV, Feo SG, Savino B, et al. Regulatory pathways in inflammation. Autoimmun Rev 2007;7:8-11.

116. Askenasy N, Kaminitz A, Yarkoni S. Mechanisms of T regulatory cell function. Autoimmun Rev 2008;7:370-5.

117. Penders J, Stobberingh EE, van den Brandt PA, Thijs C. The role of the intestinal microbiota in the development of atopic disorders. Allergy 2007;62:1223-36.

118. Adlerberth I, Strachan DP, Matricardi PM, Ahrné S, Orfei L, Åberg N, et al. Gut microbiota and development of atopic eczema in 3 European birth cohorts. J Allergy Clin Immunol 2007:120:343-50.

119. Taylor AL, Dunstan JA, Prescott SL. Probiotic supplementation for the first 6 months of life fails to reduce the risk of atopic dermatitis and increases the risk of allergen sensitization in highrisk children: a randomized controlled trial. J Allergy Clin Immunol 2007;119:184-91.

120. Abrahamsson TR, Jakobsson T, Böttcher MF, Fredrikson M, Jenmalm MC, Björkstén B, et al. Probiotics in prevention of IgEassociated eczema: a double-blind, randomized, placebo-controlled trial. J Allergy Clin Immunol 2007;119:1174-80.

121. Kalliomäki M, Salminen S, Arvilommi H, Kero P, Koskinen P Isolauri E. Probiotics in primary prevention of atopic disease: a randomised placebo-controlled trial. Lancet 2001;357:10769.

122. Kalliomäki M, Salminen S, Poussa T, Arvilommi H, Isolauri E. Probiotics and prevention of atopic disease: 4-year follow-up of a randomized placebo-controlled trial. Lancet 2003;361:186971.

123. Kalliomäki M, Salminen S, Poussa T, Isolauri E. Probiotics during the first 7 years of life: a cumulative risk reduction of eczema in a randomized, placebo-controlled trial. J Allergy Clin Immunol 2007;119:1019-21.

124. Kukkonen K, Savilahti E, Haahtela T, Juntunen-Backman K, Korpela R, Poussa T, et al. Probiotics and prebiotic galactooligosaccharides in the prevention of allergic diseases: a randomized, double-blind, placebo-controlled trial. J Allergy Clin Immunol 2007;119:192-8.

125. Kopp MV, Hennemuth I, Heinzmann A, Urbanek R. Randomized, double-blind, placebo-controlled trial of probiotics for primary prevention: no clinical effects of Lactobacillus GG supplementation. Pediatrics 2008;121:e850-6.

126. Prescott SL, Björkstén B. Probiotics for the prevention or treatment of allergic diseases. J Allergy Clin Immunol 2007;120: $255-62$.

127. Rautava S, Kalliomäki M, Isolauri E. Probiotics during pregnancy and breast-feeding might confer immunomodulatory protection against atopic disease in the infant. J Allergy Clin Immunol 2002;109:119-21.

128. Böttcher MF, Abrahamsson TR, Fredriksson M, Jakobsson T, Björkstén B. Low breast milk TGF- $\beta 2$ is induced by Lactobacillus reuteri supplementation and associates with reduced risk of sensitization during infancy. Pediatr Allergy Immunol 2008;2008 Jan 22 [Epub ahead of print].

129. Marschan E, Kuitunen M, Kukkonen K, Poussa T, Sarnesto A, Haahtela T, et al. Probiotics in infancy induce protective immune profiles that are characteristic for chronic low-grade inflammation. Clin Exp Allergy 2008;38:611-8.

130. Viljanen M, Pohjavuori E, Haahtela T, Korpela R, Kuitunen M, Sarnesto A, et al. Induction of inflammation as a possible mechanism of probiotic effect in atopic eczema-dermatitis syndrome. J Allergy Clin Immunol 2005;115:1254-9.

131. Viljanen M, Savilahti E, Haahtela T, Juntunen-Backman K, Korpela R, Poussa T, et al. Probiotics in the treatment of atopic 
eczema/dermatitis syndrome in infants: a double-blind placebocontrolled trial. Allergy 2005;60:494-500.

132. Betsi GI, Papadavid E, Falagas ME. Probiotics for the treatment or prevention of atopic dermatitis: a review of the evidence from randomized controlled trials. Am J Clin Dermatol 2008;9:93103.

133. Weston S, Halbert A, Richmond P, Prescott SL. Effects of probiotics on atopic dermatitis: a randomised controlled trial. Arch Dis Child 2005;90:892-7.

134. Brouwer ML, Wolt-Plompen SA, Dubois AE, van der Heide S, Jansen DF, Hoijer MA, et al. No effects of probiotics on atopic dermatitis in infancy: a randomized placebo-controlled trial. Clin Exp Allergy 2006;36:899-906.

135. Rosenfeldt V, Benfeldt E, Nielsen SD, Michaelsen KF, Jeppesen DL, Valerius NH, et al. Effect of probiotic Lactobacillus strains in children with atopic dermatitis. J Allergy Clin Immunol 2003; 111:389-95.

136. Pohjavuori E, Viljanen M, Korpela R, Kuitunen M, Tiittanen M, Vaarala $\mathrm{O}$, et al. Lactobacillus $\mathrm{GG}$ effect in increasing IFN- $\gamma$ production in infants with cow's milk allergy. J Allergy Clin Immunol 2004;114:131-6.

137. Prescott SL, Dunstan JA, Hale J, Breckler L, Lehmann H, Weston S, et al. Clinical effects of probiotics are associated with increased interferon- $\gamma$ responses in very young children with atopic dermatitis. Clin Exp Allergy 2005;35:1557-64.

138. Cross ML, Mortensen RR, Kudsk J, Gill HS. Dietary intake of Lactobacillus rhamnosus HNOO1 enhances production of both Th1 and Th2 cytokines in antigen-primed mice. Med Microbiol Immunol 2002;191:49-53.

139. Forsythe P, Inman MD, Bienenstock J. Oral treatment with live Lactobacillus reuteri inhibits the allergic airway response in mice. Am J Respir Crit Care Med 2007;175:561-9.

140. Feleszko W, Jaworska J, Rha RD, Steinhausen S, Avagyan A, Jaudszus A, et al. Probiotic-induced suppression of allergic sensitization and airway inflammation is associated with an increase of $\mathrm{T}$ regulatory-dependent mechanisms in a murine model of asthma. Clin Exp Allergy 2007;37:498-505.

141. Veckman V, Miettinen M, Pirhonen J, Sirén J, Matikainen S, Julkunen I. Streptococcus pyogenes and Lactobacillus rhamnosus differentially induce maturation and production of Th1-type cytokines and chemokines in human monocyte-derived dendritic cells. J Leukoc Biol 2004;75:764-71.

142. Pochard P, Gosset P, Grangette C, Andre C, Tonnel AB, Pestel J, et al. Lactic acid bacteria inhibit $\mathrm{T}_{\mathrm{H}} 2$ cytokine production by mononuclear cells from allergic patients. J Allergy Clin Immunol 2002;110:617-23.

143. Kopp MV, Goldstein M, Dietschek A, Sofke J, Heinzmann A, Urbanek R. Lactobacillus GG has in vitro effects on enhanced interleukin-10 and interferon- $\gamma$ release of mononuclear cells but no in vivo effects in supplemented mothers and their neonates. Clin Exp Allergy 2008;38:602-10.

144. Miettinen M, Matikainen S, Vuopio-Varkila J, Pirhonen J, Varkila K, Kurimoto M, et al. Lactobacilli and streptococci induce interleukin-12 (IL-12), IL-18, and gamma interferon production in human peripheral blood mononuclear cells. Infect Immun 1998;66:6058-62.

145. Van Overtvelt L, Lombardi V, Razafindratsita A, Saint-Lu N, Horiot S, Moussu H, et al. IL-10-inducing adjuvants enhance sublingual immunotherapy efficacy in a murine asthma model. Int Arch Allergy Immunol 2008;145:152-62.

146. Ishida Y, Bandou I, Kanzato H, Yamamoto N. Decrease in ovalbumin specific IgE of mice serum after oral uptake of lactic acid bacteria. Biosci Biotechnol Biochem 2003;67:9517.

147. Sunada Y, Nakamura S, Kamei C. Effects of Lactobacillus acidophilus strain L-55 on experimental allergic rhinitis in BALB/c mice. Biol Pharm Bull 2007;30:2163-6.

148. Kim H, Kwack K, Kim DY, Ji GE. Oral probiotic bacterial administration suppressed allergic responses in an ovalbumin- induced allergy mouse model. FEMS Immunol Med Microbiol 2005;45:259-67.

149. Sheth AA, Garcia-Tsao G. Probiotics and liver disease. J Clin Gastroenterol 2008;42 Suppl 2:S80-4.

150. Wiest R, Garcia-Tsao G. Bacterial translocation (BT) in cirrhosis. Hepatology 2005;41:422-33.

151. Ewaschuk J, Endersby R, Thiel D, Diaz H, Backer J, Ma M, et al. Probiotic bacteria prevent hepatic damage and maintain colonic barrier function in a mouse model of sepsis. Hepatology 2007:46:841-50.

152. Selmi C, Bowlus CL, Keen CL, Gershwin ME. Non-alcoholic fatty liver disease: the new epidemic and the need for novel nutritional approaches. J Med Food 2007;10:563-5.

153. Vollmers HP, Brandlein S. Natural antibodies and cancer. J Autoimmun 2007;29:295-302.

154. Lan RY, Selmi C, Gershwin ME. The regulatory, inflammatory, and $\mathrm{T}$ cell programming roles of interleukin-2 (IL-2). J Autoimmun 2008:31:7-12.

155. de Moreno de LeBlanc A, Matar C, Perdigon G. The application of probiotics in cancer. Br J Nutr 2007;98(Suppl 1):S105-10.

156. Perdigon G, de Moreno de LeBlanc A, Valdez J, Rachid M. Role of yoghurt in the prevention of colon cancer. Eur J Clin Nutr 2002;56(Suppl 3):S65-8.

157. de Moreno de LeBlanc A, Matar C, Theriault C, Perdigon G. Effects of milk fermented by Lactobacillus helveticus R389 on immune cells associated to mammary glands in normal and a breast cancer model. Immunobiology 2005;210:349-58.

158. Besselink MG, van Santvoort HC, Buskens E, Boermeester MA, van Goor H, Timmerman HM, et al. Probiotic prophylaxis in predicted severe acute pancreatitis: a randomised, double-blind, placebo-controlled trial. Lancet 2008;371:651-9.

159. Nagao F, Nakayama M, Muto T, Okumura K. Effects of a fermented milk drink containing Lactobacillus casei strain Shirota on the immune system in healthy human subjects. Biosci Biotechnol Biochem 2000;64:2706-8.

160. Takeda K, Okumura K. Effects of a fermented milk drink containing Lactobacillus casei strain Shirota on the human NK-cell activity. J Nutr 2007:137:791S-3S.

161. Morimoto K, Takeshita T, Nanno M, Tokudome S, Nakayama K. Modulation of natural killer cell activity by supplementation of fermented milk containing Lactobacillus casei in habitual smokers. Prev Med 2005;40:589-94.

162. Parra MD, Martínez de Morentin BE, Cobo JM, Mateos A, Martínez JA. Daily ingestion of fermented milk containing Lactobacillus casei DN114001 improves innate-defense capacity in healthy middle-aged people. J Physiol Biochem 2004;60:85-91.

163. Sheih YH, Chiang BL, Wang LH, Liao CK, Gill HS. Systemic immunity-enhancing effects in healthy subjects following dietary consumption of the lactic acid bacterium Lactobacillus rhamnosus HN001. J Am Coll Nutr 2001;20:149-56.

164. Gill HS, Rutherfurd KJ, Cross ML. Dietary probiotic supplementation enhances natural killer cell activity in the elderly: an investigation of age-related immunological changes. J Clin Immunol 2001;21:264-71

165. Chiang BL, Sheih YH, Wang LH, Liao CK, Gill HS. Enhancing immunity by dietary consumption of a probiotic lactic acid bacterium (Bifidobacterium lactis HN019): optimization and definition of cellular immune responses. Eur J Clin Nutr 2000;54: $849-55$.

166. Gill HS, Rutherfurd KJ, Cross ML, Gopal PK. Enhancement of immunity in the elderly by dietary supplementation with the probiotic Bifidobacterium lactis HN019. Am J Clin Nutr 2001; 74:833-9.

167. Klein A, Friedrich U, Vogelsang H, Jahreis G. Lactobacillus acidophilus 74-2 and Bifidobacterium animalis subsp lactis DGCC 420 modulate unspecific cellular immune response in healthy adults. Eur J Clin Nutr 2008;62:584-93.

168. Roessler A, Friedrich U, Vogelsang H, Bauer A, Kaatz M, Hipler UC, et al. The immune system in healthy adults and 
patients with atopic dermatitis seems to be affected differently by a probiotic intervention. Clin Exp Allergy 2008;38:93-102.

169. Christensen HR, Larsen CN, Kaestel P, Rosholm LB, Sternberg $\mathrm{C}$, Michaelsen KF, et al. Immunomodulating potential of supplementation with probiotics: a dose-response study in healthy young adults. FEMS Immunol Med Microbiol 2006;47:380-90.

170. Spanhaak S, Havenaar R, Schaafsma G. The effect of consumption of milk fermented by Lactobacillus casei strain Shirota on the intestinal microflora and immune parameters in humans. Eur J Clin Nutr 1998;52:899-907.

171. Kekkonen RA, Lummela N, Karjalainen H, Latvala S, Tynkkynen S, Järvenpää $S$, et al. Probiotic intervention has strain-specific anti-inflammatory effects in healthy adults. World J Gastroenterol 2008;14:2029-36.

172. Olivares M, Díaz-Ropero MP, Sierra S, Lara-Villoslada F, Fonollá J, Navas M, et al. Oral intake of Lactobacillus fermentum CECT5716 enhances the effects of influenza vaccination. Nutrition 2007;23:254-60.

173. de Vrese M, Rautenberg P, Laue C, Koopmans M, Herremans T, Schrezenmeir J. Probiotic bacteria stimulate virus-specific neutralizing antibodies following a booster polio vaccination. Eur J Nutr 2005;44:406-13.

174. Kukkonen K, Nieminen T, Poussa T, Savilahti E, Kuitunen M. Effect of probiotics on vaccine antibody responses in infancya randomized placebo-controlled double-blind trial. Pediatr Allergy Immunol 2006;17:416-21.

175. West CE, Gothefors L, Granström M, Käyhty H, Hammarström ML, Hernell O. Effects of feeding probiotics during weaning on infections and antibody responses to diphtheria, tetanus and Hib vaccines. Pediatr Allergy Immunol 2008;19:53-60.

176. Ma D, Forsythe P, Bienenstock J. Live Lactobacillus reuteri is essential for the inhibitory effect on tumor necrosis factor alphainduced interleukin-8 expression. Infect Immun 2004;72:530814.

177. Medina M, Izquierdo E, Ennahar S, Sanz Y. Differential immunomodulatory properties of Bifidobacterium logum [sic] strains: relevance to probiotic selection and clinical applications. Clin Exp Immunol 2007;150:531-8.

178. Sashihara T, Sueki N, Ikegami S. An analysis of the effectiveness of heat-killed lactic acid bacteria in alleviating allergic diseases. J Dairy Sci 2006;89:2846-55.

179. Helwig U, Lammers KM, Rizzello F, Brigidi P, Rohleder V, Caramelli E, et al. Lactobacilli, bifidobacteria and E. coli nissle induce pro- and anti-inflammatory cytokines in peripheral blood mononuclear cells. World J Gastroenterol 2006;12:5978-86.

180. Shida K, Kiyoshima-Shibata J, Nagaoka M, Watanabe K, Nanno M. Induction of interleukin-12 by Lactobacillus strains having a rigid cell wall resistant to intracellular digestion. J Dairy Sci 2005;89:3306-17.

181. Matsuguchi T, Takagi A, Matsuzaki T, Nagaoka M, Ishikawa K, Yokokura T, et al. Lipoteichoic acids from Lactobacillus strains elicit strong tumor necrosis factor alpha-inducing activities in macrophages through Toll-like receptor 2. Clin Diagn Lab Immunol 2003;10:259-66.

182. Iliev ID, Kitazawa H, Shimosato T, Katoh S, Morita H, He F, et al. Strong immunostimulation in murine immune cells by $\mathrm{Lac}$ tobacillus rhamnosus GG DNA containing novel oligodeoxynucleotide pattern. Cell Microbiol 2005;7:403-14; Erratum, 611.

183. Kitazawa H, Watanabe H, Shimosato T, Kawai Y, Itoh T, Saito T. Immunostimulatory oligonucleotide, $\mathrm{CpG}$-like motif exists in Lactobacillus delbrueckii ssp. bulgaricus NIAI B6. Int J Food Microbiol 2003;85:11-21.

184. Kitazawa H, Ueha S, Itoh S, Watanabe H, Konno K, Kawai Y, et al. AT oligonucleotides inducing B lymphocyte activation exist in probiotic Lactobacillus gasseri. Int $\mathrm{J}$ Food Microbiol 2001:65:149-62.

185. Takahashi N, Kitazawa H, Shimosato T, Iwabuchi N, Xiao JZ, Iwatsuki K, et al. An immunostimulatory DNA sequence from a probiotic strain of Bifidobacterium longum inhibits IgE produc- tion in vitro. FEMS Immunol Med Microbiol 2006;46:4619.

186. Takahashi N, Kitazawa H, Iwabuchi N, Xiao JZ, Miyaji K, Iwatsuki K, et al. Oral administration of an immunostimulatory DNA sequence from Bifidobacterium longum improves Th1/Th2 balance in a murine model. Biosci Biotechnol Biochem 2006;70: 2013-7.

187. Iliev ID, Tohno M, Kurosaki D, Shimosato T, He F, Hosoda M, et al. Immunostimulatory oligodeoxynucleotide containing TTTCGTTT motif from Lactobacillus rhamnosus GG DNA potentially suppresses OVA-specific IgE production in mice. Scand J Immunol 2008;67:370-6.

188. Zeuthen LH, Fink LN, Frøkiær H. Toll-like receptor 2 and nucleotide-binding oligomerization domain-2 play divergent roles in the recognition of gut-derived lactobacilli and bifidobacteria in dendritic cells. Immunology 2008;124:489-502.

189. Karlsson H, Hessle C, Rudin A. Innate immune responses of human neonatal cells to bacteria from the normal gastrointestinal flora. Infect Immun 2002;70:6688-96.

190. Ichikawa S, Fujii R, Fujiwara D, Komiyama Y, Kaisho T, Sakaguchi M, et al. MyD88 but not TLR2, 4 or 9 is essential for IL-12 induction by lactic acid bacteria. Biosci Biotechnol Biochem 2007;71:3026-32.

191. Baken KA, Ezendam J, Gremmer ER, de Klerk A, Pennings JL, Matthee B, et al. Evaluation of immunomodulation by Lactobacillus casei Shirota: immune function, autoimmunity and gene expression. Int J Food Microbiol 2006;112:8-18.

192. Ezendam J, van Loveren H. Lactobacillus casei Shirota administered during lactation increases the duration of autoimmunity in rats and enhances lung inflammation in mice. $\mathrm{Br} \mathrm{J}$ Nutr 2008;99:83-90.

193. Maassen CB, van Holten JC, Balk F, Heijne den BakGlashouwer MJ, Leer R, Laman JD, et al. Orally administered Lactobacillus strains differentially affect the direction and efficacy of the immune response. Vet Q 1998;20:S81-3.

194. Maassen CB, Claassen E. Strain-dependent effects of probiotic lactobacilli on EAE autoimmunity. Vaccine 2008;26:2056-7.

195. Baharav E, Mor F, Halpern M, Weinberger A. Lactobacillus GG bacteria ameliorate arthritis in Lewis rats. J Nutr 2004;123: 1964-9.

196. So JS, Kwon HK, Lee CG, Yi HJ, Park JA, Lim SY, et al. Lactobacillus casei suppresses experimental arthritis by downregulating T helper 1 effector functions. Mol Immunol 2008;45: 2690-9.

197. Kato I, Endo-Tanaka K, Yokokura T. Suppressive effects of the oral administration of Lactobacillus casei on type II collageninduced arthritis in DBA/1 mice. Life Sci 1998;63:635-44.

198. Calcinaro F, Dionisi S, Marinaro M, Candeloro P, Bonato V, Marzotti S, et al. Oral probiotic administration induces interleukin-10 production and prevents spontaneous autoimmune diabetes in the non-obese diabetic mouse. Diabetologia 2005;48: $1565-75$.

199. Ratajczak C, Duez C, Grangette C, Pochard P, Tonnel AB, Pestel J. Impact of lactic acid bacteria on dendritic cells from allergic patients in an experimental model of intestinal epithelium. J Biomed Biotechnol 2007;2007:71921. Epub 2007 Feb 28.

200. Pelto L, Isolauri E, Lilius EM, Nuutila J, Salminen S. Probiotic bacteria down-regulate the milk-induced inflammatory response in milk-hypersensitive subjects but have an immunostimulatory effect in healthy subjects. Clin Exp Allergy 1998;28: 1474-9.

201. Pochard P, Hammad H, Ratajczak C, Charbonnier-Hatzfeld AS, Just N, Tonnel AB, et al. Direct regulatory immune activity of lactic acid bacteria on Der p 1-pulsed dendritic cells from allergic patients. J Allergy Clin Immunol 2005;116:198-204.

202. Christensen HR, Frøkiær H, Pestka JJ. Lactobacilli differentially modulate expression of cytokines and maturation surface markers in murine dendritic cells. J Immunol 2002;168:171-8. 
203. Kim H, Lee SY, Ji GE. Timing of Bifidobacterium administration influences the development of allergy to ovalbumin in mice. Biotechnol Lett 2005;27:1361-7.

204. Peng S, Lin JY, Lin MY. Antiallergic effect of milk fermented with lactic acid bacteria in a murine animal model. J Agric Food Chem 2007;55:5092-6.

205. Ohno H, Tsunemine S, Isa Y, Shimakawa M, Yamamura H. Oral administration of Bifidobacterium bifidum G9-1 suppresses total and antigen specific immunoglobulin E production in mice. Biol Pharm Bull 2005;28:1462-6.

206. Torii A, Torii S, Fujiwara S, Tanaka H, Inagaki N, Nagai H. Lactobacillus acidophilus strain L-92 regulates the production of Th1 cytokine as well as Th2 cytokines. Allergol Int 2007;56:293301.

207. Segawa S, Nakakita Y, Takata Y, Wakita Y, Kaneko T, Kaneda H, et al. Effect of oral administration of heat-killed Lactobacillus brevis SBC8803 on total and ovalbumin-specific immunoglobulin E production through the improvement of Th1/Th2 balance. Int J Food Microbiol 2008;121:1-10.

208. Matsuzaki T, Yamazaki R, Hashimoto S, Yokokura T. The effect of oral feeding of Lactobacillus casei strain Shirota on immunoglobulin E production in mice. J Dairy Sci 1998;81: $48-53$.

209. Fujiwara D, Inoue S, Wakabayashi H, Fujii T. The anti-allergic effects of lactic acid bacteria are strain dependent and mediated by effects on both Th1/Th2 cytokine expression and balance. Int Arch Allergy Immunol 2004;135:205-15.

210. Nonaka Y, Izumo T, Izumi F, Maekawa T, Shibata H, Nakano A, et al. Antiallergic effects of Lactobacillus pentosus strain S-PT84 mediated by modulation of Th1/Th2 immunobalance and induction of IL-10 production. Int Arch Allergy Immunol 2008;145:249-57.

211. Hisbergues M, Magi M, Rigaux P, Steuve J, Garcia L, Goudercourt D, et al. In vivo and in vitro immunomodulation of Der p 1 allergen-specific response by Lactobacillus plantarum bacteria. Clin Exp Allergy 2007;37:1286-95.

212. Ruiz PA, Hoffmann M, Szcesny S, Blaut M, Haller D. Innate mechanisms for Bifidobacterium lactis to activate transient proinflammatory host responses in intestinal epithelial cells after the colonization of germ-free rats. Immunology 2005;115:441-50. 